\title{
Sosyal Bilgiler Ders Kitaplarında Cinsiyet Rolleri
}

\author{
DOI: 10.26466/opus.686709
}

\section{Mehmet Tahir Karaboğa *}

* Dr. Öğretim Üyesi, Mersin Üniversitesi, Eğitim Fakültesi, Mersin/Türkiye E-Posta: tahirkaraboga@gmail.com

ORCID: $\underline{0000-0003-0795-7991}$

\section{Öz}

Bu çalışmanın amacı ortaokullarda okutulan sosyal bilgiler ders kitaplarında yer alan görsel öğelerin kadın ve erkek cinsiyet rolleri açısından incelenmesidir. Araştırmada ortaokul sosyal bilgiler ders kitaplarında yer alan görsel öğelerde yetişkin kadın ve erkekler ile kız ve erkek çocukların "kimlerle birlikte gösterildiği, hangi eylemler, mekânlar, meslekler ve objelerle birlikte gösterildikleri" incelenmiştir. Araştırmanın örneklemini 2019-2020 eğitim öğretim yllında Milli Ĕ̆itim Bakanlı̆̆ınca ortaokullarda okutulmak üzere seçilen 5, 6, ve 7. sinnf sosyal bilgiler ders kitaplarındaki görsel öğeler oluşturmaktadır. Bu çalışma nitel bir çalışma olup doküman incelemesi tekniği ile sosyal bilgiler ders kitaplarında yer alan görseller üzerine yapılan bir içerik çözümlemesini içermektedir. Yapılan araştırmada incelenen ortaokul sosyal bilgiler ders kitaplarında yer alan görsellerin cinsiyet rollerine uygun öğeler içerdiği belirlenmiştir. Ders kitaplarının bu yolla cinsiyete dayalı rollerin öğretilmesi, pekiştirilmesi ve yeniden üretilmesine katkı sağladığı görülmektedir. Bulgular ortaokul sosyal bilgiler ders kitaplarında yer alan kız ve erkek çocuk ile yetişkin kadın ve erkek görsellerinin cinsiyete dayal kalıplar içerdiğini ortaya koymaktadır

Anahtar Kelimeler: Cinsiyet, Toplumsal Cinsiyet, Toplumsal Cinsiyet Rolleri, Ortaokul Sosyal Bilgiler Ders Kitabı.. 


\title{
Gender Roles in Social Studies Textbooks
}

\begin{abstract}
The aim of this study is to examine the visual elements in social studies textbooks taught in secondary schools in terms of gender roles. In the study, the visual elements in the secondary school social studies textbooks were examined in terms of with whom, in what actions, in which places, in which professions and with what objects adult women and men and girls and boys were shown. The sample of the research includes visual items in the 5, 6, and 7th grade social studies textbooks selected by the Ministry of National Education to be taught in secondary schools in the 2019-2020 academic year. This study is a qualitative study and includes a document analysis technique and a content analysis on the visuals in the social studies textbooks. In the research, it has been determined that the visuals in the secondary school social studies textbooks contain elements based on gender roles. It is seen that textbooks contribute to teaching, reinforcement and reproduction of gender-based roles in this way. The findings reveal that the images of boys and girls and adult women and men in the secondary school social studies textbooks contain gender stereotypes.
\end{abstract}

Keywords: Gender, Gender Roles, Gender in Textbooks, Secondary School Social Studies Textbook. 


\section{Giriş}

Kadın ve erkek rollerinin toplumsal süreçlerde oluşmuş kalıp yargılardan beslendiği bilinen bir olgudur. Kadınlar ve erkeklere atfedilen toplumsal rollere ilişkin duygu, tutum ve davranışlar önemli ölçüde toplumsal yaşamın içindeki kurum ve yapılarca şekillenir. Bireylerde cinsiyet rollerini içselleştirme ve toplumun kabulleri doğrultusunda şekillenme sürecinin, ailede başlayarak okuldaki eğitim süreciyle devam ettiğini ve geliştirilerek pekiştirildiğini söylemek mümkündür. Aile, sosyal çevre, medya ve okul gibi kurum ve yapılar kadın ve erkek rollerine ilişkin bir takım kalıp yargılar üretebilmekte, bu da onların toplumsal imkan ve olanaklardan yararlanabilme düzeylerine ilişkin engeller oluşturabilmektedir.

Okuldaki eğitim süreci, sosyal yaşamın en önemli alanlarından biri olmakla birlikte, ulusal kimliğin geliştirilmesi, yaratıcı ve üretken bireylerin yetiştirilmesi, çağdaş normlara göre kaliteli bir eğitimin inşa edilmesi ve fursat eşitliğinin sağlanmasında önemli derecede rol oynar. Çabuk Kaya (2013) Türkiye'de eğitim kurumlarında toplumsal cinsiyet eşitsizliklerinin, ekonomik, sosyal, ailevi bileşenler içeren çok boyutlu ve karmaşık bir sosyolojik sorun olduğunu belirtir. Okuldaki eğitim sürecinde işlevsel unsurlardan birisi de ders kitaplarıdır. Ders kitapları öğrenmenin gerçekleşmesini sağlayan materyallerin başında gelir. Ders kitapları öğrenmeyi kolaylaştırmalarının yanında içeriğinde kullanılan dilsel ve görsel anlatımlarla çocuk bireylerin, bilişsel, duyuşsal ve sosyal gelişimlerinde rol oynar.

Sosyal bilgiler ders kitabı, barındırdığı söylem ve görsel öğelerle öğrencilerin topluma, bireye ve çevreye yönelik bakış açılarının şekillenmesinde etkili olan temel eğitim basamağının önemli ders materyallerindendir. Bu nedenle toplum içinde yer alacak çocuk bireylerin nitelikli bir şekilde yetiştirilmesinde, cinsiyet rol eşitliğinin öğretilmesinde, konuya yönelik eşitlikçi bir bakış açısının oluşturulmasında sosyal bilgiler ders kitaplarının önemi azımsanamaz. Bu bağlamda ülkemizde toplumsal cinsiyet eşitliğinin sağlanması ve konuya yönelik farkındalığı artırmaya yönelik çabaların yaygınlaştırılması toplumsal gelişim açısından önem arz etmektedir. 


\section{Toplumsal Cinsiyet Rolleri ve Eğitim}

Bayhan (2013) cinsiyet kavramının kadın ya da erkek olmanın biyolojik yönünü ifade eden ve biyolojik bir yapıya karşılık gelen bir terim olduğunu ifade eder. Dökmen (2016) ise, cinsiyet kavramını bireyin biyolojik cinsiyetine dayalı olarak belirlenen, doğumla beraber üreme organı ayrımına göre adlandırılarak kimliklendirilme olarak tanımlamaktadır. Buna karşılık toplumsal cinsiyet kavramı ise, kadın veya erkek olmaya yönelik toplumun veya kültürün yüklediği anlamları ve beklentileri ifade eden bir kavram olarak karşımıza çıar. Oakley'e göre (1972) toplumsal cinsiyet, erkeklik ve kadınlık arasındaki toplumsal bakımdan eşit olmayan bölünmeyi ifade etmektedir. Bhasin (2003), toplumsal cinsiyetin kültürel ve toplumsal bir olgu olmasının temel göstergesi olarak, zaman içerisinde toplumdan topluma değişmesi ve evrilmesini gösterir. Connell (2019), toplumsal cinsiyet kavramını kişinin cinsiyetiyle belirlenen genel bir rolün öğrenilip içselleştirilmesi olarak ifade eder. Farklı toplumsal beklentilere cevap veren bireylerin, cinsiyete dayalı rollerindeki ayrım, toplumsal cinsiyet kavramıla kategorize edilebilir. Connell'e göre, biyolojik bir cinsiyete sahip olarak doğan bir çocuk, büyüdükçe toplumsallaşmakta, bu süreçte aile başta olmak üzere toplumsal dinamikler davranış modelleri ve cinsiyete uygun rollerin geliştirmesine neden olmaktadır. Toplumsallaşma süreciyle birlikte çocuğa aktarılan davranış kalıpları cinsiyet ayrımına göre şekillenmektedir.

Rol kavramıyla kadın ve erkeğin toplumdaki görevleri, sorumlulukları, kimliği, hakları, değer üretimi sürecindeki toplumun onlardan beklediği tüm davranış ve düşünme yapısının toplamı olarak ifade edilebilir. Toplumdaki cinsiyet rollerinin öğrenilmesi süreci objeler, oyuncaklar, kıyafetler, meslekler ve dil gibi pek çok alan üzerinden kendisini gösterir. Alpan Özdemir'e (2018) göre "cinsiyetlerin ve cinsiyet rollerinin çocuklara öğretilmesi aileden, sosyal çevreden sağlandığı gibi reklam, televizyon, gazete, dergi, klip, şarkı sözü gibi kitle iletişim araçları ile çocuk öyküleri, masallar ve ders kitaplarından da sağlanır" (s.81). Francis'e göre (2006), kadınlar ve erkeklere atfedilen toplumsal rol ve konumlar önemli ölçüde toplumsal yaşamın örgütlenme şekline göre belirlenmekte, pek çok toplumda erkeklere ilişkin iş ve etkinlikler üstün konumlarla özdeşleştirilmektedir. Dökmen (2016) toplumsal cinsiyet farklılıklarının doğuştan değil, kazanılmış özellikler olduğunu düşünmekte- 
dir. MacNaughton (2006) da çocukların erken yaşlardan itibaren cinsiyet rollerini öğrendiklerini belirtir. Butler (2008) ise, cinsiyetin biyolojik-fiziksel bir sürecin ürünü olduğunu, toplumsal cinsiyeti ise verili roller ile inşa edilmiş bir yaratımın bir ürünü olduğunu söyler. Bu bağlamda toplumsal cinsiyetin getirdiği kadın ve erkek rollerinin içeriği zamana ve yere göre değiştiğini, bir kader olmadığını, eşit olmayan bir toplumsal inşa sürecinin ürünü olduğunu belirtir.

Çocuk, cinsiyetine bağlı olarak aile ve çevresindeki kadın ve erkek rollerini toplumdaki etkileşim sayesinde öğrenir. Birey, eğitim aracilı̆ıyla toplumsal bütünlüğe katılım sağlarken kişilik ve değer gelişimi deneyimleri yoluyla edinir. Aile bu sürecin birinci basamağını oluştururken ikinci basamağını eğitim kurumları oluşturmaktadır. Dökmen'e (2016) göre, okul bireylerin toplumsallaşmasını sağlarken bir yandan da onlara toplumsal cinsiyet rollerini kazandırır. Toplumsallaşma sürecinin ilk ortamı olan aile, bireye cinsiyetine bağlı olarak bir takım davranış modellerini öğretir. Bu eğitim şeklini informal eğitim olarak tanımlayan Bay (2011), bu eğitim sürecinin kendiliğinden ve plansız geliştiğini, genellikle yaşamsal alanlarda gözlem ve taklit yoluyla oluştuğunu ifade eder.

Çocuklar ilk olarak kendi cinsiyet kimliklerini ve sonra başkalarınınkini öğrenirler. Ailede başlayan rol ayrışması, okuldaki eğitim süreci boyunca da çeşitli öğeler aracilığıyla pekiştirilmektedir. Örneğin müfredat ve ders kitaplarının içeriği, öğretmenlerin geleneksel tutumları ve arkadaşlardan edinilen bazı davranışlar bu yönde belirleyici bir etkiye sahiptir. İlköğretimin özellikle ilk sınıflarında kullanılan ders kitaplarında, okula adımını yeni atmış ve toplumsallaşma sürecinin güçlü olduğu bir yaşam sürecinde olan çocuklara nasıl kadın ve erkek olacakları öğretilmektedir (Vatandaş, 2011).

Çocuklar erken yaşlardan başlayarak televizyonda izledikleri çizgi filmler, reklamlar, diziler yoluyla internette izledikleri, oynadıkları videolar ve oyunlarla bir takım davranışlar öğrenirler. Daha sonra okulda veya arkadaş gruplarıyla bu ortamlarda öğrendiği davranışları uygulamaya geçirirler. Okulda cinsiyet rolleri müfredat, öğretmenler, materyaller ve ders kitapları aracılığıyla öğretilebilmektedir. Çocukların oyuncakları, saç ve giyim şekilleri, kullandıkları objeler cinsiyetlerine ayrılarak tercih, istek, davranış, oyun gibi araçlar aracılığıyla cinsiyet rollerini öğretilebilmektedir. 
Çocukların zihninde gelişen kalıp yargılar, kadın ve erkek rollerine ilişkin şablonlar, özellikle eğitimin toplumsallaştırma işlevinin ön hazırlıklarının yapıldığ1 ilköğretim kademesinde, cinsiyetçi değerlerin ve toplumsal cinsiyet kimliklerinin üretildiği bir alan olarak ortaya çıkmaktadır. Cinsiyet rollerine ilişkin alginın eğitim süreçlerinde öğrenildiğini belirten Gündüz Kalan'a göre, "cinsiyete özgü şekillenen bu algı biçimi eğitim hayatı boyunca çocuğu etkilemekle beraber, arkadaşlık ilişkilerini, evliliğe bakışı, meslek seçimini etkilemekte, çocuğun hayatını yönlendirmesinde etkili olmaktadır. Basmakalıp yargıların etkisi altında kalan birey, özgür seçimler yapamaz ve kendini rahat ifade edemez. Bu da bireyin kişisel başarısı ve hayat tatminini olumsuz yönde etkileyebilmektedir" (Gündüz Kalan, 2010, s. 81).

Türkiye Büyük Millet Meclisi raporunda atıfta bulunulan Birleşmiş Milletler Kalkınmada Kadının Rolü Dünya Araştırması raporuna (1999) göre, "Toplumsal cinsiyet, ideolojik ve kültürel bir yapı olmakla birlikte, maddi uygulama sahasında yeniden üretilir; karşılığında da bu uygulamaların sonuçlarını etkiler. Toplumsal cinsiyet, kaynakların, zenginliklerin, işin, karar yetkisinin ve siyasal gücün dağılımını, gerek kamusal yaşamda gerekse ailede hak ve kazanımlardan nasıl ve ne ölçüde yararlanıldığını belirler. Toplumsal cinsiyet bir anlamda ırk, sınıf, etnik köken, cinsellik ve yaş gibi diğer sınıflandırıcılar gibidir. Toplumsal cinsiyet kimliklerinin toplumda nasıl inşa edildiğini ve cinsiyetler arasındaki ilişkileri belirleyen eşitsiz güç ilişkilerini anlamamıza yardımc olur" (TBMM, 1999, s.64).

Toplumsal süreçte bireylerin cinsiyete dair kalıp yargıları ile toplumdaki kadın ve erkek rollerinin inşasında kimlerin etkin olduğu sorusunu akla getirebilir. Bu çerçeveden bakıldığında bireyin aile içinde model aldığı, özdeşim kurduğu kişilerin toplumun kalıplarına ve kurallarına ne denli uyduğu veya bu kalıplara uygun olarak sergilediği davranışlar önemli olmaktadır. Çocuğun toplumsal alanın cinsiyet rollerine ilişkin olarak öğretilerini ilk olarak aldığı ailenin yanı sıra okulun da bir diğer önemli kaynağı oluşturduğu söylenebilir. Bu bağlamda okul, bireylerde temel yaşam becerilerinin geliştirilmesinin yanı sıra cinsiyete dayalı eşitlik çerçevesindeki sosyal tecrübelerini de gerçekleşebileceği bir ortam sunabilir. Bireyin yaşamın içinden veya çevresinden gözlemlediği cinsiyet rollerini kalıplaştırması anlamında ilköğretim önemli bir aşamadır. Bu nedenle ilköğretim aşaması toplumsal cinsiyet eşitliği açısından da önemli bir süreci karşılamakta ve sürecin yönetiminde eğitim alanındaki düzenlemelerin önemli bir rolü bulunmaktadır. 
Fidan ve Elden'e (1996) göre okul, toplumdaki bireyleri eğitme işlevini üstlenen önemli kurumların başında gelmektedir. Okullar toplumun beklentileri doğrultusunda hazırlanan bir program çerçevesinde öğretim faaliyeti yürüterek, öğrencilerin davranışlarında değişiklik meydana getirmeyi amaçlar. Okullarda eğitim bir program, plan ve hedef çerçevesinde gerçekleştirilir. Bilgi beceri ve tutumlar öğrencilere önceden belirlenmiş program çerçevesinde uzman eğitimciler tarafından kazandırılır. Tezcan (1996), eğitimin öncelikli temel işlevlerinin kültürel mirasın yeni kuşaklara aktarılması, bireylere mesleki bilgi ve becerilerin kazandırılması olduğunu belirtir. Tezcan'a göre, bu mirasın içinde toplumsal cinsiyet kalıp yargıları da bulunmaktadır. Aile ortamında öğretilmeye başlanan toplumsal cinsiyet kalıp yargıları okuldaki eğitim sürecinde de devam eder. Öğrenci "kadın” ve "erkek" cinsiyet rollerini öğrenerek benimser. Jacklin (1983), hem bir eğitim hem de sosyalleşme alanı olarak çocuk kitapları ve ders kitaplarında cinsiyetçi kalıp yargıların görüldügünü belirtir. Jacklin'e göre, çocuk kitaplarında kadınlar geleneksel anne rolü ile temsil edilmekte, erkekler ise daha çeşitli rol ve işler ile temsil edilmektedirler.

Kuzgun ve Sevim'e (2004) göre, okullarda toplumsal cinsiyet rollerine ilişkin kalıp yargılar açık ya da örtülü bir şekilde çocuklara öğretilebilmektedir. Örtük ya da doğrudan verilen bilgiler ile çocuklar geleneksel cinsiyet rollerine uygun davranışlarda bulunurlar. Bununla birlikte, okullarda okutulan ders kitapları yoluyla da kadın ve erkeğe ilişkin toplumsal cinsiyet rolleri gelecek kuşaklara aktarılır. Kılavuz (2019) ilkokul eğitiminde toplumsal cinsiyet ilişkilerinin yer aldığını, öğretmenlerin de toplumun geleneksel cinsiyet bakış açısından etkilenerek, öğrencilere cinsiyetçi kodlar taşıyabildiklerini belirtmektedir. Kılavuz yürüttüğü araştırmada, öğretmenlerin cinsiyetçi kodları, sınıf içi süreçlere yansıtabildiklerini; doğrudan ya da dolaylı olarak eğitim uygulamalarında cinsiyetçi farklılaşmalara zemin hazırlayabildiklerini ve toplumsal cinsiyet ayrımcllğının yeniden üretimine aracılık ettiklerini tespit etmiştir.

Balcı Karaboğa (2019), kız ve erkek çocukların cinsiyetçi temelde eğitim almalarının, katı cinsiyet kalıp yargılarına ve rollerine uygun eğitilmelerinin, onların okul başarılarını, beceri edinimlerini ve ileriki yaşamlarında kazanacakları mesleklerini ve statülerini de etkilediğini belirtir. Balcı Karaboğa, cinsiyet rollerinin ve kalıp yargıların çocuk okul çağına geldiği zaman da devam ettiğini, hem eğitime erişim hem de okul içi süreçlerde cinsiyetçi ayrışmanın 
varlığını sürdürdüğünü belirtmektedir. Ayrıca, ders kitap ve materyallerinde yer alan cinsiyetçi unsurlar, öğrenme etkinlikleri sırasında pekiştirilen cinsiyet temelli tutum ve davranışlar, öğretmen öğrenci etkileşimi gibi okul süreçlerinin pek çok boyutuna ilişkin yapılan araştırmaların bulgularında da eğitimdeki cinsiyetçi süreçlerinin tespit edildiğini vurgulamaktadır.

\section{Sosyal bilgiler ders kitaplarnda toplumsal cinsiyet rolleri}

Toplumsal cinsiyet rollerinin oluşumu ve gelişiminde cinsiyet rollerinin çocuklara öğretilmesinde başta aile olmak üzere kitle iletişim araçları, akran etkileri yanı sıra okuldaki eğitim sürecinin bir parçası olan ders kitaplarının da önemli rol oynadığını söylemek mümkündür. Demirel ve Kıroğlu'na (2006) göre ders kitapları, bir eğitim programında yer alan hedef, içerik, öğretme öğrenme süreci ile ölçme değerlendirme boyutlarına uygun olarak hazırlanmış ve öğrenme amaçlı kullanılan basılı bir öğretim materyalidir. Eğitimde kullanılan ders kitapları öğrenciye belirlenen hedefler doğrultusunda birtakım bilgi, beceri ve değerler kazandırması, rehberlik etmesi, yol gösterici olması nedeniyle eğitim programının önemli bir boyutunu oluşturur. Tietz (2007), ders kitaplarının cinsiyet rolleri hakkında örtük mesajlar ve öğeler içerdiğini bu öğeler aracilığıyla bireye cinsiyet rollerine ait beklentilerin ve davranışların öğretildiğini belirtir. Öğrenci ders kitabı aracilığıyla örtük ya da açık mesajlar ile öğrendiklerini davranışa veya düşünceye dönüştürür. Demokratik bir toplumun yaratılmasında, sorumluluklarının bilincinde olan yurttaşların yetiştirilmesinde, vatandaşlık becerilerinin oluşturulmasında ve en önemlisi toplumsal cinsiyet rollerinin edinilmesinde sosyal bilgiler ders kitapları ayrı bir öneme sahiptir.

Tezer Asan (2010), ders kitaplarının toplumsal cinsiyet rollerinin üretildiği bir içerik ve söylemin yanı sıra ayrımcı bakış açısına dayanan göstergeleri de taşıdığını belirtir. Ayrıca cinsiyete dair ayrımcılık açısından ders kitaplarının yanı sıra öğrenci için rol model olan öğretmenin de cinsiyet bağlamındaki bakış açısının oluşmasında etkileri olabilmektedir. Tezer Asan'a (2010) göre "cinsiyetçiliğe ilişkin öğretmen algıları, inançları ve kabulleri eğitim sürecinde geleneksel cinsiyetçiliğin yeniden üretilmesinde ders kitaplarının yanında çok daha ayrı bir önem arz etmektedir" (Tezer Asan, 2010, s.68). 
TBMM CEDAW (1993) komitesine sunulmak üzere hazırlanan ikinci ve üçüncü birleştirilmiş periyodik Türkiye raporuna göre, eğitimdeki materyallerin geleneksel toplum yapısiyla uyumlu olarak okullarda okutulan ders kitaplarının cinsiyetçiliğe dayalı kalıp yargılar içerdiği belirtilmektedir. Ders materyallerinde kadınlar daha çok anne ve eş rolü ile yan yana getirilerek özdeşleştirilmekte, kız çocuklarına daha çok anne rolü, erkek çocuklarına ise daha çok baba rol model sunularak, bir takım kalıplar içinde gösterildiği ve kalıp yargılara görsel ve yazılı öğelerde sıkça yer verildiği ifade edilmektedir. XV. Milli Eğitim Şurasında eğitim programının, kitap ve iletilerinin cinsiyete dayalı kalıp yargılarından arındıılması, kadınların kamusal yaşama, erkeklerin aile ve ev yaşamına etkin katılımını, aile içi rol ve sorumluluk paylaşımında bireylere daha esnek tutumlar kazandırılmasının tüm örgün ve yaygın eğitim programlarının hazırlanmasında göz önüne alınması gerektiği vurgulanmıştır

Bu bağlamda 1993 yılından sonra değerlendirilen çalışmalara bakıld1ğında Gümüşoğlu (2016) ve Altan Arslan (2000) yaptığı ders kitaplarında cinsiyetçilik konulu çalışmalarında, ilköğretimden başlayarak çocuklara sistematik olarak kadın ve erkeğin nasıl olması gerektiğinin anlatıldığına ve kadının toplumsal sınırlar içinde edilgen olarak tanımlandığına vurgu yapılmaktadır. Tezer Asan’a göre, "kendi varlığını ve içinde yaşadığı sosyal yapılanmayı, kültürü yeni kavrayan ilköğretim öğrencilerine verilecek her cinsiyetçi değer daha uzun yıllar o ülkenin kültüründe cinsiyetçiliğin diri ve canlı tutulacağını, cinsler arası eşitsizlik ve dengesizliğin devam edeceğini göstermektedir" (Tezer Asan, 2010, s. 68). Yurtsever (2011) ise, ders kitaplarında kadınların çoğunlukla klasik roller içerisinde ve ev ortamlarında temsil edildiğini, erkeklerin ise daha çok baskın otoriter ve güçlü rollerde gösterildiğini belirtir. Yurtsever'e göre, ders kitapları aracılığıyla çocuklar kadınların ev işleri ile erkeklerin ise ev dışındaki sosyal ortamlarda ve işlerde çalışması gerektiğini normal bir şey olduğunu öğretir.

Temel eğitim basamağında yer alan sosyal bilgiler dersi çocukları tüm toplumsal süreçlere hazırlamada başat derslerden biri olarak önemli bir yer tutmaktadır. Sosyal bilgiler eğitiminin başlıca hedefi; Türkiye Cumhuriyeti vatandaşlarının yaşadığı topraklara aidiyet bilinci geliştirmiş, haklarını bilen, bireysel ve toplumsal sorumlulukların yerine getiren, millî bilince sahip birer vatandaş olarak yetiştirilmeleridir. Bunu yaparken Atatürk ilke ve inkılâpla- 
rının, izinde demokratik, laik, millî ve çağdaş değerleri yaşatan bireyler yetiştirmeyi de amaçlamaktadır. Ayrıca kültürel değerlerine sahip çıkan, küresel dünya düzeninde yer almak için gereken bilgi ve donanıma sahip, toplumsal sorunlara duyarlı ve çözüm yolu arayan, insan hakları ve her tür eşitliği savunan, özgür birer birey olarak kendisinin farkına varmasını da amaçlamaktadir.

MEB'e (2018) göre, sosyal bilgiler dersi bireyin düşünme, yaratıcılık ve sorgulama yeteneklerinin gelişmesinde etkili olurken, bireyin kendini en iyi şekilde ifade etmesine de olanak sağlar. İlköğretim basamağında yer alan sosyal bilgiler dersinin bu denli önemli hedefleri açısından cinsiyet rollerine yaklaşımı büyük önem arz etmektedir. Bu konuda yapılan çalışmalardan birinde Demirel (2010), sosyal bilgiler ders kitaplarının, çocukların aile içi ve toplumsal iş bölümü konularında etkileri olabildiğini, kitaplarda çocukların ebeveynleriyle özdeşleştirilerek, önyargı ve kalıplar doğrultusunda, benzer tutum ve davranış eğilimleri içerisinde gösterildiklerini belirtmektedir. Demirel'e göre ders kitaplarında kadın ile yan yana getirilen meslekler, başta ev kadınlığı olmak üzere, öğretmenlik, çiftçilik dadılık-hizmetçilik, tezgâhtarlık, terzilik ve hemşirelik gibi meslekler olmaktadır. Erkekler ise çok sayıda meslekle temsil edilmekte, erkek figürler sosyal bilgiler ders kitaplarında, hemşirelik mesleği dışında neredeyse tüm iş kollarında yer almaktadır.

Ünsal ve Güneş (2002) ilköğretim ders kitaplarını tanımlarken, öğretim programlarında yer alan konulara ait, gelişimsel dönemler de temel alınarak hazırlanan, içerik ve bilgileri planlı bir biçimde açıklayan, ders esnasında öğrenilen bilgilerin okul dışında da tekrarını sağlayan ve dersin hedefleri doğrultusunda yönlendiren temel bir ortam olarak ifade etmektedir. Ders kitapları, öğretim sürecinin tamamlayıcı öğretim materyalleri olarak da tanımlanabilir. Demirel ve Kıroğlu'na göre (2006), ders kitabı, bir eğitim müfredatına uygun olarak öğrenmeye yardımcı olmak amacıyla hazırlanmış öğretim materyalidir. Ünsal ve Güneş (2002) de ders kitaplarının, sınıf seviyelerine ve ders öğretim programlarına uygun olarak hazırlanmış en önemli materyaller olduğunu ifade ederler. Sosyal bilgiler dersinin bu denli önemli olmasının yanı sıra ders içinde kullanılan materyallerden biri olan ders kitaplarının da özenli bir şekilde ve hedeflerle örtüşecek nitelikte olması gerektiği söylenebilir.

Eğitim kurumlarında okutulan ders kitaplarında toplumsal yapının ve kültürün iz düşümünü takip etmek mümkündür. Bu yönüyle ders kitapları 
cinsiyete ait rollerin yazılı ve görsel olarak tekrar üretilmesi ve betimlenmesinde önemli bir etmendir. Eğitimle toplumsal hayata hazırlanırken hem evde hem de okulda kurulan cinsiyete ait bağların pekiştirilmesinde ders kitaplarının önemli bir kaynak oluşturduğu ifade edilebilir. Bu anlamda kitaplar cinsler arası eşitliği hedefleyen bir mücadele alanı olarak da değerlendirilebilir. Bunun için de eğitim alanında yaşamsal önem taşıyan sosyal bilgiler ders kitaplarının, kadın ve erkek rolleri ile ilişkili kavramları aktarırken eşitlikçi bir yapıda sunmaları beklenmektedir. Böylelikle gelecekte özel yaşamları ile kamusal yaşamları arasında bağ kurulurken eşitlikçi anlayış sergileyecek bir neslin temellerinin bu süreçte atılabileceği düşünülmektedir.

Çakır'a (2013) göre eğitim sürecinde metin ve görsel öğelerden meydana gelen ders kitapları, çocuklara yön veren, çocukta farkındalık oluşturan önemli materyallerin başında gelmektedir. Batur'a (2010) göre kitaplarda yer alan görsel öğeler çocukların düşünce dünyalarının şekillenmesinde oldukça önemli rol oynarlar. Bu bağlamda ders kitaplarında yer alan metin ve görsel öğelerde cinsiyet ayrımının yapılmaması, eşitlikçi bir görünüm sergilenmesi önem arz etmektedir. Cinsiyete ait ayrımcilıkla mücadelede, henüz toplumsal yaşamın temellerinin atıldığı ilköğretim döneminde farkındalığı arttırıcı nitelikte konu ve içeriklerle birlikte, konuların pekiştirilmesi/içselleştirilmesi anlamında kitaplar, sınıfta ise bu bakış açısını sergileyebilen öğretmenle mümkündür. Amaç insan haklarına saygıll, eşitlikçi bireylerin yetiştirilmesidir.

\section{Araştırmanın Amacı}

Bu çalışmanın amacı, ortaokullarda okutulan sosyal bilgiler ders kitaplarının görsellerini toplumsal cinsiyet rolleri bağlamında incelemektir. Elde edilen bulgular ışığında bu kitapların toplumsal cinsiyet eşitsizliğini doğurup doğurmadığı veya toplumda cinsiyet eşitliğine dayalı bir ortam sağlamaya yönelik öğeleri içerip içermediği ortaya konmaya çalışılmaktadır. Okullar toplumsal cinsiyet rollerinin öğretilmesinde ve yeniden üretilmesinde rol oynayan kurumların başında gelir. Okullardaki eğitim sürecinde ders kitapları önemli araçlardır. Ders kitapları çocukların toplumsal kimliklerinin şekillenmesinde önemli bir role sahiptir. Ders kitapları kadın erkek cinsiyet rollerinin eşitlik bağlamında olumlu ya da olumsuz anlamda etki edebilmektedir. 
Ders kitaplarının cinsiyet rolleri bakımından eşitlikçi bir yapıya dayanması cinsiyet ayrımına dayanmayan bir anlayışın geliştirilmesinde katkı sağlayabilir. Bu anlamda Milli Eğitim Bakanlığı tarafından okullarda okutulan ders kitapların içeriklerinin nasıl olduğu, bu içeriklerde toplumsal cinsiyet öğelerinin olup olmadığının araştırılması önem taşımaktadır. Ortaokul döneminde öğrenciler çocukluktan gençliğe geçiş aşamasında ve kendi kimliklerini bulma yolunda arayış içerisindedirler. Öğrenciler bu dönemde kimlik arayışı ve kendilerini farklı bir birey olarak kabul ettirme çabaları gösterebilmektedir. Ortaokul yıllarında başlayan ve zor bir dönem olan ergenliğin sağlıklı bir şekilde geçirilip kişinin kendi kimliğini kazanması çok önemlidir. $\mathrm{Bu}$ dönemde edinilen roller ve yaşantıların etkileri ömür boyu sürebilmektedir. Bu nedenle bu dönemde karşılaşılan ve yaşantılanan cinsiyet rollerine ilişkin bakış açısı, demokratik bir toplumun inşa edilmesinde ve cinsiyet eşitsizliklerinin önüne geçmede önemli hale gelmektedir.

\section{Yöntem}

$\mathrm{Bu}$ araştırmada doküman incelemesi tekniği kullanılmıştır. Illköğretimin 5, 6 ve 7. sınıf sosyal bilgiler ders kitapları incelenmiştir. Dökümanlar Milli Eğitim Bakanlığı tarafından onaylanmış ve 2019-2020 eğitim-öğretim sürecinde devlet okullarında okutulan ders kitaplarıdır. Nitel araştırmada doğrudan gözlem ve görüşmenin olanaklı olmadığı durumlarda, çalışılan araştırma problemiyle ilişkili görsel ve yazılı materyaller de araştırmaya dâhil edilebilir" (Yıldırım ve Şimşek, 2018, s. 189). Araştırma kapsamında ders kitaplarındaki görseller konuya ilişkin literatürde başvurulan kategoriler de referans alınarak içerik analizine tabi tutulmuştur. "İçerik analizinde temel amaç, toplanan verileri açıklayabilecek kavramlara ve ilişkilere ulaşmaktır" (Yıldırım ve Şimşek, 2018, s.242). "İçerik analizi, sözel yazılı verilere, sonradan istatistik işlemlerin uygulanabilmesine ve belirli bir kavram, görüş, durum, özellik ya da değişken hakkında önemli bilgiler edinmeye olanak sağlar"'(Tavşancıl ve Aslan, 2001, s.21). Bu çalışmanın amacı ortaokullarda Milli Eğitim Bakanlığı (MEB) Talim Terbiye Kurulu'nun izniyle okutulan sosyal bilgiler ders kitaplarının içinde yer alan görsellerin cinsiyet rolleri açısından incelenmesidir. $\mathrm{Bu}$ doğrultuda aşağıdaki sorular cevaplanmaya çalışılmaktadır. 
1- Ortaokul sosyal bilgiler ders kitaplarında yer alan görsel öğelerde yetişkin kadın ve erkekler ile kız ve erkek çocuklar kimlerle birlikte gösterilmektedir?

2- Ortaokul sosyal bilgiler ders kitaplarında yer alan görsel öğelerde yetişkin kadın ve erkekler ile kız ve erkek çocuklar hangi eylemler içerisinde gösterilmektedirler?

3- Ortaokul sosyal bilgiler ders kitaplarında yer alan görsel öğelerde yetişkin kadın ve erkekler ile kız ve erkek çocuklar hangi mekânlarda gösterilmektedirler?

4- Ortaokul sosyal bilgiler ders kitaplarında yer alan görsel öğelerde yetişkin kadın ve erkek figürlerin meslekleri nelerdir?

5- Ortaokul sosyal bilgiler ders kitaplarında yer alan görsel öğelerde yetişkin kadın ve erkekler ile kız ve erkek çocuklar hangi objelerle gösterilmektedirler?

\section{Araştırma Modeli}

Bu çalışma nitel bir çalışma olup doküman incelemesi tekniği ile sosyal bilgiler ders kitaplarında yer alan görseller içerik analizi ile çözümlenmiştir. Dökümanlar nitel araştırmalarda önemli bilgi kaynaklarıdır. Araştırmalarda hangi dokümanların önemli olduğu araştırma problemi ile yakından ilgilidir. Örneğin eğitim ile ilgili bir araştırmada veri kaynağı olarak ders kitapları, öğretim programları ve eğitimle ilgili diğer resmi belgeler kullanılabilmektedir (Yıldırım ve Şimşek, 2013). Yıldırım ve Şimşek'e göre, fotoğraflar, videolar veya okunabilen diğer nitel veriler, içerik analizi yapmak için uygundur.

\section{Örneklem}

Araştırmanın örneklemi, 2019-2020 eğitim öğretim yılında MEB ortaokul 5, 6, 7. sınıf sosyal bilgiler ders kitaplarının görsellerinden oluşmaktadır.

\section{Verilerin Analizi}

Milli Eğitim Bakanlığı tarafından ortaokullarda 2019-2020 Eğitim Öğretim döneminde okutulması öngörülen Sosyal Bilgiler 5, 6 ve 7. sınıf ders kitapla- 
rındaki görseller araştırma sorularında belirtilen kategorilere göre analiz edilmiştir. Kitaplarda toplam 443 görsel incelenmiştir. İncelenen görsellerden elde edilen veriler tablolara dönüştürülmüş̧ür. Sosyal bilgiler ders kitapları incelenirken Özdemir ve Balcı Karaboğa'nın (2019) “Ders kitaplarında cinsiyetçilik: ortaokul matematik ders kitapları üzerine bir içerik analizi", Kitiş Çınar'ın (2013) "İlköğretim Türkçe ders kitaplarında toplumsal cinsiyet” ve Esen Severge'nin (1998) “Ders kitaplarında cinsiyetçilik: İlköğretim ders kitapları üzerinde yapılmış bir içerik çözümlemesi" adlı çalışmalarında geliştirdikleri kategoriler temel alınmıştır. Bu çalışmada ortaokul sosyal bilgiler ders kitaplarında yer alan görsel öğelerde yetişkin kadın ve erkekler ile kız ve erkek çocukların kimlerle birlikte gösterildikleri, hangi eylemler içerisinde gösterildikleri, hangi mekânlarda gösterildikleri, hangi mesleklerde gösterildikleri ve hangi nesnelerle gösterildikleri kategorileri çerçevesinde incelenmiştir.

\section{Bulgular ve Yorum}

Bu bölümde örneklemi oluşturan ortaokul 5, 6 ve 7. sınıf sosyal bilgiler ders kitaplarının içinde yer alan görsellerin toplumsal cinsiyet rolleri açısından incelenmesi sonucu elde edilen bulgular ve bu bulgulara ait yorumlar yer almaktadır. Araştırmanın örnekleminde yer alan 3 sosyal bilgiler ders kitabında toplam 443 görsel fotoğraf incelenmiştir. Bulgular toplamda 14 adet tablo aracılığı ile araştırmanın alt soruları çerçevesinde sunulmuştur.

Ortaokul sosyal bilgiler ders kitaplarnda yer alan görsel öğelerde yetişkin kadın ve erkekler ile kız ve erkek çocuklar kimlerle birlikte gösterilmektedir?

Tablo 1. Kız ve erkek çocuk figürlerin birlikte gösterildikleri kişilere göre frekans ve yüzde dağılımları

\begin{tabular}{lllll}
\hline & K1z figürler & \multicolumn{2}{l}{ Erkek figürler } \\
\cline { 2 - 5 } & $\mathrm{f}$ & $\%$ & $\mathrm{f}$ & $\%$ \\
\hline Tek başına & 19 & 25,33 & 24 & 33,33 \\
\hline Çocuk ve çocuklarla & 25 & 33,33 & 21 & 29,17 \\
\hline Yetişkinlerle & 18 & 24 & 14 & 19,44 \\
\hline Ailesi ile & 4 & 5,33 & 2 & 2,77 \\
\hline Kalabalık ile & 9 & 12 & 11 & 15,27 \\
\hline Toplam & 75 & 100 & 72 & 100 \\
\hline
\end{tabular}


75'i kız, 72'si erkek olan toplam figürlerde kız ve erkek çocukların en çok birlikte gösterildikleri kişiler incelendiğinde erkek çocuk figürlerin en çok tek başına, kız çocuk figürlerin ise diğer çocuk ve çocuklarla birlikte gösterildikleri tespit edilmiştir.

İncelenen ders kitaplarında kız figürlerin sırasıyla, çocuk ve çocuklar ile $(\% 33,33)$, tek başına (\% 25,33), yetişkinlerle (\% 24), kalabalık ile (\% 12), ailesiyle (\% 5,33) gösterildikleri görülmüştür. Erkek çocuk figürlerin ise sirasıyla, tek başına (\% 33,33), çocuk ve çocuklar ile (\% 29,17), yetişkinlerle $(\% 19,44)$, kalabalık ile (\% 15,27), ailesiyle (\% 2,77) gösterildikleri belirlenmiştir.

Tablo 2. Toplam çocuk figürleri içinde kız ve erkek çocuk figürlerin birlikte gösterildikleri kişilerin frekans ve yüzde dağılımlan

\begin{tabular}{lllllll}
\hline & \multicolumn{2}{l}{ Kız figürler } & \multicolumn{2}{l}{ Erkek figürler } & Toplam & \\
\cline { 2 - 7 } & $\mathrm{f}$ & $\%$ & $\mathrm{f}$ & $\%$ & $\mathrm{f}$ & $\%$ \\
\hline Tek başına & 19 & 12,93 & 24 & 16,33 & 43 & 29,25 \\
\hline Çocuk ve çocuklarla & 25 & 17 & 21 & 14,28 & 46 & 31,29 \\
\hline Yetişkinlerle & 18 & 12,24 & 14 & 9,52 & 32 & 21,77 \\
\hline Ailesi ile & 4 & 2,72 & 2 & 1,36 & 6 & 4,08 \\
\hline Kalabalık ile & 9 & 6,12 & 11 & 7,48 & 20 & 13,61 \\
\hline Toplam & 75 & 51,02 & 72 & 48,98 & 147 & 100 \\
\hline
\end{tabular}

İncelenen sosyal bilgiler ders kitaplarında toplam kız ve erkek çocuk figür sayısı içinde erkek ve kızların görünürlüğüne bakıldığında, kızlar (\%51,02) ile erkeklere (\%48,97), birbirine yakın neredeyse eşit oranda yer verildiği göze çarpmaktadır. Bu anlamda ortaokul sosyal bilgiler kitaplarında kız ve erkek çocuk figürlere yer verilme oranlarında önemli bir farklılığın ortaya çımadığını ve bu konuda özen gösterildiğini söyleyebiliriz.

Buna rağmen toplam çocuk sayısı içinde çocukların kimlerle gösterildiklerini incelediğimizde bir farkın ortaya çıktığını görüyoruz. Tek başına gösterilen figürler içinde kızların \% 12,93 erkeklerin \% 16,33 oranında yer aldığı, diğer çocuk ve çocuklarla gösterilme oranının kızlarda \% 17 iken, erkeklerin çocuklarla gösterilme oranının \% 14,28 olduğu görülmüştür. Kızların yetişkinlerle $\% 12,24$, erkelerde $\% 9,52$ oranında, kız çocukların ailesiyle ile birlikte $\%$ 2,72, erkeklerin ise $\% 1,36$ oranında gösterildiği; kızların kalabalık ile $\%$ 6,12 oranında, erkeklerin kalabalık ile \% 7,48 oranında gösterildiği belirlenmiştir. Kız çocuk figürlerin aileleriyle birlikte gösterileme oranının yüksek olması, erkek çocukların ise tek başına ve kalabalık ile gösterilme oranını yüksek ol- 
ması; çocukların büyüdüklerinde tek başına ve kalabalık içerisinde dolaşmanın uygun olmadığı, erkek çocukların ise tek başına ve kalabalık ile özgür dolaşabileceği algısının yerleşmesine olanak verebileceğini söylemek mümkündür.

Sosyal bilgiler ders kitaplarında yer alan figürlerin kimlerle birlikte gösterildiği konusu yetişkin figürler için de incelenmiş ve sonuçlar aşağıdaki tabloda gösterilmiştir.

Tablo 3. Yetişkin kadın ve erkek figürlerin birlikte gösterildikleri kişilere göre frekans ve yüzde dă̆ılımı

\begin{tabular}{lllll} 
& \multicolumn{2}{l}{ Kadın figürler } & \multicolumn{2}{l}{ Erkek figürler } \\
\cline { 2 - 5 } & $\mathrm{f}$ & $\%$ & $\mathrm{f}$ & $\%$ \\
\hline Tek başına & 11 & 18,97 & 114 & 47,90 \\
\hline Çocuk ve çocuklarla & 9 & 15,52 & 5 & 2,10 \\
\hline Ailesi ile & 5 & 8,62 & 5 & 2,10 \\
\hline Kalabalık ile & 2 & 3,44 & 10 & 4,20 \\
\hline Sadece kadınlar ile & 10 & 17,24 & 3 & 1,26 \\
\hline Sadece erkek ile & 2 & 3,44 & 82 & 34,45 \\
\hline Kadınlar ve erkekler ile & 19 & 32,76 & 19 & 7,98 \\
\hline Toplam & 58 & 100 & 238 & 100 \\
\hline
\end{tabular}

Yetişkin kadın ve erkek figürlerin incelenen ders kitaplarındaki temsil oranları açısından önemli bir fark bulunmuştur. 238 yetişkin erkek figüre karşın 58 yetişkin kadın tespit edilmiştir. Yetişkin kadın ve erkek figürlerin birlikte gösterildikleri kişilere göre frekans ve yüzde dağılımlarına baktı̆̆1mızda; yetişkin kadın figürlerin sırasıyla, kadın ve erkeklerle $\% 32,76$, tek başına $\% 18,97$, sadece kadınlarla $\% 17,24$, çocuk ve çocuklarla $\% 15,52$, ailesiyle $\%$ 8,62 oranlarında gösterildiği belirlenmiştir. Yetişkin erkek figürlerin ise s1rasıyla, tek başına $\% 47,90$, sadece erkekler ile $\% 47,90$, kalabalık ile $\%$ 4,20, çocuk ve çocuklarla \% 2,10, ailesiyle \% 2,10 oranlarda gösterildiği tespit edilmiştir.

Burada en belirgin farklılık noktası, yetişkin kadın ve erkek figürlerin ders kitaplarındaki temsil oranlarında erkeklerin lehine büyük bir farklılığın bulunmuş olmasıdır. Yetişkin erkek figürleri yetişkin kadın figürleriyle karşılaştırdığımızda ortaya çkan diğer önemli fark ise, erkeklerin kadınlara göre tek başına gösterilme oranlarının yüksek olması, kadın figürlerin ise çocuk ve çocuklar ile gösterilme oranının erkeklere oranla daha yüksek bulunması olmuştur. Bunlarla birlikte yetişkin kadın figürlerin sadece kadınlarla birlikte, 
yetişkin erkek figürlerin sadece erkek figürler birlikte gösterilme oranlarının yüksek olması da bir diğer dikkat çekici nokta olmuştur.

Tablo 4. Toplam yetişkin figürleri içinde kadın ve erkek figürlerin birlikte gösterildikleri kişilerin frekans ve yüzde dağılımlan

\begin{tabular}{lllllll}
\hline & \multicolumn{2}{l}{ Kadın figürler } & \multicolumn{2}{l}{ Erkek figürler } & \multicolumn{2}{l}{ Toplam } \\
\cline { 2 - 7 } & $\mathrm{f}$ & $\%$ & $\mathrm{f}$ & $\%$ & $\mathrm{f}$ & $\%$ \\
\hline Tek başına & 11 & 3,72 & 114 & 38,51 & 125 & 42,23 \\
\hline Çocuk ve çocuklarla & 9 & 3,04 & 5 & 1,69 & 14 & 4,73 \\
\hline Ailesi ile & 5 & 1,69 & 5 & 1,69 & 10 & 3,38 \\
\hline Kalabalık ile & 2 & 068 & 10 & 3,38 & 12 & 4,05 \\
\hline Sadece kadınlarla & 10 & 3,38 & 3 & 1,01 & 13 & 4,39 \\
\hline Sadece erkeklerle & 2 & 0,67 & 82 & 27,70 & 84 & 28,38 \\
\hline Kadınlar ve erkeklerle & 19 & 6,42 & 19 & 6,42 & 38 & 12,84 \\
\hline Toplam & 58 & 19,59 & 238 & 80,41 & 296 & 100 \\
\hline
\end{tabular}

Tablo 4'te toplam yetişkin figürleri içinde kadın ve erkek figürlerin birlikte gösterildikleri kişilerin frekans ve yüzde dağılımlarına baktığımızda; kadın yetişkin figürlerin tek başına gösterilme oranlarının (\% 3,72), erkek yetişkin figürlerinkinden (\% 38,51) oldukça düşük olduğu görülmektedir. Toplam yetişkin figürleri içinde kadın figürler daha çok kadın ve erkeklerle (\% 6,42), tek başına (\% 3,72), sadece kadınlarla (\% 3,38) ve çocuklarla (\% 3,04) ve gösterilmiştir. Toplam yetişkin figürleri içinde erkeklerin ise daha çok tek başına (\% $38,51)$, sadece erkeklerle (\% 27,70), kadın ve erkeklerle (\% 6,42) gösterildiği görülmüştür. Bu bağlamda erkek figürlerin daha çok tek başına ve erkeklerle gösterildiği ve yetişkin erkeklerin çocuklarla ve kadınlarla birlikte gösterildiği figürlere daha az yer verildiği görülmüştür. Kadın figürlerin ise en az erkeklerle ve kalabalık ile gösterilmesi göze çarpmaktadır.

Ortaokul sosyal bilgiler ders kitaplarında yer alan görsel öğelerde yetişkin kadın ve erkekler ile kız ve erkek çocuklar hangi eylemler içerisinde gösterilmektedirler?

Ders kitaplarında yer alan görsel öğelerde yetişkin kadın ve erkekler ile kız ve erkek çocuklar hangi eylemler içerisinde gösterildikleri; okula ve öğrenmeye yönelik eylem, oyun ve eğlenceye yönelik eylemler, kültür ve sanata yönelik eylemler, kültür ve sanata yönelik eylemler, sosyal eylemler, evdeki 
eylemler, kişisel eylemler eylemsiz ve diğer olmak üzere 9 alt kategoride incelenmiştir. Analizler önce çocuk figürlerin yer aldığı görsellerde yürütülmüştür.

Tablo 5. Kız ve erkek çocuk figürlerin eylemlerinin frekans ve yüzde dă̆ılımları

\begin{tabular}{lllll}
\hline & \multicolumn{2}{l}{ K1z figürler } & \multicolumn{2}{c}{ Erkek figürler } \\
\cline { 2 - 5 } & $\mathrm{f}$ & $\%$ & $\mathrm{f}$ & $\%$ \\
\hline Okula ve öğrenmeye yönelik eylemler & 15 & 20 & 18 & 25 \\
\hline Oyun ve eğlenceye yönelik eylemler & 6 & 8 & 7 & 9,72 \\
\hline Kültür ve sanata yönelik eylemler & 7 & 9,33 & 4 & 5,55 \\
\hline Spora yönelik eylemler & 1 & 1,33 & 2 & 2,77 \\
\hline Sosyal eylemler & 12 & 16 & 14 & 19,44 \\
\hline Evdeki eylemler & 6 & 8 & 4 & 5,55 \\
\hline Kişisel eylemler & 0 & 0 & 1 & 1,39 \\
\hline Eylemsiz & 18 & 24 & 12 & 16,67 \\
\hline Diğer & 10 & 13,33 & 10 & 13,89 \\
\hline Toplam & 75 & 100 & 72 & 100 \\
\hline
\end{tabular}

İncelenen kitapların görsellerinde kız ve erkek figürlerin yaptıkları eylemlere bakıldığında kız figürlerin sırasıyla eylemsiz (\% 24) gösterildikleri, daha sonra okula ve öğrenmeye yönelik eylem (\% 20), sosyal eylemler (\% 16), diğer (\% 13,33) , kültür ve sanata yönelik eylemler (\% 9,33), evdeki eylemler (\% 8), oyun ve eğlenceye yönelik eylemler (\% 8) eylemler içinde gösterildikleri belirlenmiştir. Erkek çocuk figürler ise, sırasıyla okula ve öğrenmeye yönelik eylemler (\% 25), sosyal eylemler (\% 19,44), eylemsiz (\% 16,67), diğer (\% 13,89), oyun ve eğlenceye yönelik eylemler (\% 9,72) oranlarında gösterilmişlerdir.

Kız çocuk figürler ile erkek çocuk figürleri karşılaştırdığımızda kız çocukların erkeklerden daha çok eylemsiz halde gösterildikleri, bunun yanı sıra evdeki eylemlerde, kültür ve sanata yönelik eylemlerde kız çocuklara erkeklerden daha çok yer verildiği; erkek çocuk figürlere ise okula ve öğrenmeye yönelik eylemler, oyun ve eğlenceye yönelik eylemler, spora yönelik eylemler, sosyal eylemlerde kızlardan daha çok yer verildiği görülmüştür.

Toplam çocuk figürleri içinde kız ve erkek figürlerin eylemlerinin frekans ve yüzde dağılımları incelendiğinde aşağıdaki sonuçlara ulaşılmıştır. 
Tablo 6. Toplam çocuk figürleri içinde kız ve erkek figürlerin eylemlerinin frekans ve yüzde dağılımlan

\begin{tabular}{lllllll}
\hline & \multicolumn{2}{c}{ Kiz figürler } & \multicolumn{2}{c}{ Erkek figürler } & \multicolumn{2}{c}{ Toplam } \\
\cline { 2 - 7 } & $\mathrm{f}$ & $\%$ & $\mathrm{f}$ & $\%$ & $\mathrm{f}$ & $\%$ \\
\hline Okula ve öğrenmeye yönelik eylem & 15 & 10,20 & 18 & 12,24 & 33 & 22,44 \\
\hline Oyun ve Eğlenceye Yönelik Eylemler & 6 & 4,08 & 7 & 4,76 & 13 & 8,84 \\
\hline Kültür ve Sanata Yönelik Eylemler & 7 & 4,76 & 4 & 2,72 & 11 & 7,48 \\
\hline Spora Yönelik Eylemler & 1 & 0,68 & 2 & 1,36 & 3 & 2,04 \\
\hline Sosyal Eylemler & 12 & 8,16 & 14 & 9,52 & 26 & 17,69 \\
\hline Evdeki eylemler & 6 & 4,08 & 4 & 2,72 & 10 & 6,80 \\
\hline Kişisel eylemler & 0 & 0 & 1 & 0,68 & 1 & 0,68 \\
\hline Eylemsiz & 18 & 12,24 & 12 & 8,16 & 30 & 20,41 \\
\hline Diğer & 10 & 6,80 & 10 & 6,80 & 20 & 13,61 \\
\hline Toplam & 75 & 51,02 & 72 & 48,98 & 147 & 100 \\
\hline
\end{tabular}

İncelenen kitaplardaki görsellerde kız ve erkek figürlerin eylemlerine eylemsiz olma durumu ve diğer kategorilerinin dışında baktığımızda; kız çocuk figürlerin daha çok okula ve öğrenmeye yönelik eylemlerde (\% 10,20), sosyal eylemlerde (\% 8,16), kültür ve sanata yönelik eylemlerde (\% 4,76), evdeki eylemlerde $(\% 4,08)$, oyun ve eğlenceye yönelik eylemlerde $(\% 4,08)$ gösterildikleri tespit edilmiştir. Erkek çocuk figürler daha çok okula öğrenmeye yönelik eylemlerde (\% 12,24), sosyal eylemlerde (\% 9,5), oyun ve eğlenceye yönelik eylemlerde $(\% 4,76)$ oranında gösterilirken en az kültür ve sanata yönelik eylemlerde (\% 2,72), evdeki eylemlerde (\% 2,72) oranlarında gösterilmişlerdir.

Yetişkin kadın ve erkek figürlerin eylemlerinin incelendiği analiz sonuçlarına aşağıdaki tabloda yer verilmiştir.

Tablo 7. Yetişkin kadın ve erkek figürlerin eylemlerinin frekans ve yüzde dağılımlan

\begin{tabular}{lllll} 
& \multicolumn{2}{c}{ Kadın figürler } & \multicolumn{2}{c}{ Erkek figürler } \\
\cline { 2 - 5 } & $\mathrm{f}$ & $\%$ & $\mathrm{f}$ & $\%$ \\
\hline Çocuğa Yönelik/Çocukla İlgili Eylem & 7 & 12,07 & 6 & 2,52 \\
\hline Boş Zamana Yönelik Eylemler & 8 & 13,79 & 19 & 7,98 \\
\hline Kültürel/Sanatsal Eylemler & 4 & 6,90 & 10 & 4,20 \\
\hline Eve yönelik eylemler & 4 & 6,90 & 1 & 0,42 \\
\hline İşe Yönelik Eylemler & 13 & 22,41 & 90 & 37,81 \\
\hline Sosyal Eylemler & 12 & 20,69 & 24 & 10,08 \\
\hline Eylemsiz & 7 & 12,07 & 81 & 34,03 \\
\hline Diğer & 3 & 5,17 & 7 & 2,94 \\
\hline Toplam & 58 & 100 & 238 & 100 \\
\hline
\end{tabular}

Yetişkin kadın figürlerin en çok işe eylemlerde (\% 22,41), daha sonra sosyal eylemlerde $(\% 20,69)$ ve boş zaman yönelik eylemlerde $(\% 13,79)$, çocuğa 
yönelik eylemlerde $(\% 12,07)$ ve eylemsiz $(\% 12,07)$ gösterildikleri görülmektedir. Erkek figürlerin de ilk sırada işe yönelik eylemlerde $(\% 37,81)$, daha sonra eylemsiz $(\% 34,03)$ gösterildikleri bunu sosyal eylemlerin $(\% 10,08)$ ve boş zaman yönelik eylemlerin $(\% 7,98)$ izlediği görülmektedir.

Tablo 8. Toplam yetişkin figürleri içinde kadın ve erkek figürlerin eylemlerinin cinsiyete göre frekans ve yüzde dağılımlar

\begin{tabular}{lllllll} 
& \multicolumn{2}{l}{ Kadın figürler } & \multicolumn{2}{c}{ Erkek figürler } & \multicolumn{2}{l}{ Toplam } \\
\cline { 2 - 7 } & $\mathrm{f}$ & $\%$ & $\mathrm{f}$ & $\%$ & $\mathrm{f}$ & $\%$ \\
\hline Çocuğa Yönelik/Çocukla İlgili Eylem & 7 & 2,36 & 6 & 2,03 & 13 & 4,395 \\
\hline Boş Zamana Yönelik Eylemler & 8 & 2,70 & 19 & 6,41 & 27 & 9,12 \\
\hline Kültürel/Sanatsal Eylemler & 4 & 1,35 & 10 & 3,38 & 14 & 4,73 \\
\hline Eve yönelik eylemler & 4 & 1,35 & 1 & 0,34 & 5 & 1,69 \\
\hline İşe Yönelik Eylemler & 13 & 4,39 & 90 & 30,41 & 103 & 34,80 \\
\hline Sosyal Eylemler & 12 & 4,05 & 24 & 8,11 & 36 & 12,16 \\
\hline Eylemsiz & 7 & 2,36 & 81 & 27,36 & 88 & 29,73 \\
\hline Diğgr & 3 & 1,01 & 7 & 2,36 & 10 & 3,38 \\
\hline Toplam & 58 & 19,59 & 238 & 80,41 & 296 & 100
\end{tabular}

Tablo 8'de incelenen görsellerde hem kadın hem erkek figürler en çok işe yönelik eylemlerde (\% 34,80), sonra eylemsiz durumda (\% 29,73), sosyal eylemlerde (\% 12,16), kültürel/sanatsal eylemlerde (\% 4,39), çocuğa yönelik/çocukla ilgili eylemlerde $(\% 4,73)$ gösterildikleri göze çarpmaktadır. Kadınların sırasıyla işe yönelik eylemlerde $\% 4,5$, sosyal eylemlerde ( $\% 4,05)$, boş zamana yönelik eylemlerde \% 2,70, çocuğa yönelik/çocukla ilgili eylemlerde (\% 2,36) gösterildiği görülmektedir. Erkek figürlerin ise sırasıyla en çok işe yönelik eylemlerde (\% 34,80), eylemsiz (\% 27,36), sosyal eylemlerde (\% 8,11), boş zamana yönelik eylemlerde (\% 6,41), kültür ve sanata yönelik eylemlerde (\% $3,38)$ gösterildiği görülmüştür.

İncelenen kitaplardaki görsellerde toplam yetişkin figürleri içinde kadın figürler eve yönelik eylemlerde ve çocuğa yönelik/çocukla ilgili eylemlerde erkeklerden daha çok yer alırken; erkekler ise boş zamana yönelik eylemler, kültürel/sanatsal eylemler, işe yönelik eylemler, sosyal eylemler açısından kadınlardan daha çok yer buldukları tespit edilmiştir. İşe yönelik eylemler açısından erkek ve kadın figürler arasındaki temsil oranı farkı en yüksektir. 
Ortaokul sosyal bilgiler ders kitaplarnda yer alan görsel öğelerde yetişkin kadın ve erkekler ile kız ve erkek çocuklar hangi mekânlarda gösterilmektedirler?

Bu soru çerçevesinde ders kitaplarındaki görsellerde yer alan yetişkin kadın ve erkek ile kız ve erkek çocuk figürler ev ve ev çevresi, okul ve okul çevresi, dış mekân, kurum ve kuruluş, iş ortamı ve belirsiz mekan kategorilerinde incelenmiştir.

Tablo 9. Kiz ve erkek çocuk figürlerinin gösterildiği mekânlara göre frekans ve yüzde dağllimlarn

\begin{tabular}{lllll} 
& \multicolumn{2}{c}{ Kız figürler } & \multicolumn{2}{c}{ Erkek figürler } \\
\cline { 2 - 6 } & $\mathrm{f}$ & $\%$ & $\mathrm{f}$ & $\%$ \\
\hline Ev ve Ev Çevresi & 19 & 25,33 & 10 & 13,88 \\
\hline Okul ve Okul Çevresi & 21 & 28 & 26 & 36,11 \\
\hline Diş Mekân & 22 & 29,33 & 24 & 33,33 \\
\hline Kurum ve Kuruluş & 1 & 1,33 & 2 & 2,78 \\
\hline İş Ortamı & 0 & 0 & 1 & 1,39 \\
\hline Belirsiz & 12 & 16 & 9 & 12,5 \\
\hline Toplam & 75 & 100 & 72 & 100 \\
\hline
\end{tabular}

Tablo 9' da kız çocuk figürlerin gösterildiği mekanlara baktığımızda, dış mekân (\% 29,33), okul ve okul çevresi (\% 28), ev ve ev çevresi (\% 25,33), belirsiz (\% 16), kurum ve kuruluşta (\% 1,33) olduğu görülmekte; erkek çocuk figürlerine baktığımızda sırasıyla okul ve okul çevresi (\% 36,11), dış mekân (\% $33,33)$, ev ve ev çevresi (\% 13,88), belirsiz mekan (\%12,5), kurum ve kuruluş $(\% 2,78)$ gibi mekanlarda gösterildikleri görülmektedir.

Tablo 10. Toplam çocuk figürleri içinde kız ve erkek çocuk figürlerinin gösterildiği mekânlarm frekans ve yüzde dağılımları

\begin{tabular}{lllllll}
\hline & \multicolumn{2}{l}{ Kız figürler } & \multicolumn{2}{l}{ Erkek figürler } & \multicolumn{2}{l}{ Toplam } \\
\cline { 2 - 8 } & $\mathrm{f}$ & $\%$ & $\mathrm{f}$ & $\%$ & $\mathrm{f}$ & $\%$ \\
\hline Evv ve Ev Çevresi & 19 & 12,93 & 10 & 6,80 & 29 & 19,73 \\
\hline Okul ve Okul Çevresi & 21 & 14,29 & 26 & 17,69 & 47 & 31,97 \\
\hline Diş Mekân & 22 & 14,97 & 24 & 16,33 & 46 & 31,29 \\
\hline Kurum ve Kuruluş & 1 & 0,68 & 2 & 1,36 & 3 & 2,04 \\
\hline İş Ortamı & 0 & 0 & 1 & 0,68 & 1 & 0,68 \\
\hline Belirsiz & 12 & 8,16 & 9 & 6,12 & 21 & 14,29 \\
\hline Toplam & 75 & 51,02 & 72 & 48,98 & 147 & 100 \\
\hline
\end{tabular}


Tablo 10'da toplam çocuk figürleri içinde kız ve erkek figürlerinin gösterildiği mekânları incelediğimizde kız ve erkek çocuk figürlerin daha çok okul ve okul çevresinde \% 31,97, dış mekânlarda $(\% 31,29)$ yer verildiği görülmektedir. Kız figürler en çok dış mekan (14,97), okul ve okul çevresinde (\% 12,93), ev ve ev çevresinde (\% 12,93) gösterilirken; dış mekanlarda ve kurum ve kuruluşlarda en az gösterilmiştir. Erkek çocuk figürler ise en çok, okul ve okul çevresinde (\% 17,69), dış mekanda (\% 16,33), ev ve ev çevresinde (\% 6,80) gösterilmiştir. İncelen kitaplarda kız ve erkek çocuk figürlerin en çok okul çevresinde dış mekanda ve ev ve ev çevresinde gösterildikleri belirlenmiştir. Aynı zamanda kız çocuklarının ev ve ev çevresinde gösterilme oranları erkeklerin ev ve ev çevresinde gösterilme oranından fazla olurken; erkek çocuk figürlerin okul ve okul çevresinde, dış mekanda kızlara göre gösterilme oranları ise daha yüksek olmuştur.

Yetişkin kadın ve erkek figürlerin mekanlara göre dağılımı incelenerek aşağıdaki tabloda sunulmuştur.

Tablo 11. Kadın ve erkek figürlerin gösterildiği mekâna göre frekans ve yüzde dağılımlan

\begin{tabular}{lllll}
\hline & \multicolumn{2}{c}{ Kadın figürler } & \multicolumn{2}{c}{ Erkek figürler } \\
\cline { 2 - 6 } & $\mathrm{f}$ & $\%$ & $\mathrm{f}$ & $\%$ \\
\hline Ev ve Ev Çevresi & 10 & 17,24 & 13 & 5,46 \\
\hline Okul ve Okul Çevresi & 4 & 6,90 & 1 & 0,42 \\
\hline Diş Mekân & 16 & 27,59 & 95 & 39,92 \\
\hline Kurum ve Kuruluş & 5 & 8,62 & 11 & 4,62 \\
\hline İş Ortamı & 21 & 36,21 & 84 & 35,29 \\
\hline Belirsiz & 2 & 3,45 & 34 & 14,29 \\
\hline Toplam & 58 & 100 & 238 & 100 \\
\hline
\end{tabular}

Tablo 11'de kadın ve erkek figürlerin gösterildiği mekânları incelediğimizde kadın figürlerin sırasıyla en çok iş ortamında (\% 36,21), dış mekanda (\% 27,59), ev ve ev çevresinde (\% 17,24), kurum ve kuruluşlarda (\% 8,62), okul ve okul çevresinde $(\% 6,90)$ gösterilmiştir. Erkek figürler ise, diş mekanda (\% $39,92)$, iş ortamında $(\% 35,29)$, ev ve ev çevresinde (\% 5,46), kurum ve kuruluşlarda $(\% 4,62)$ gösterilmişlerdir. 
Tablo 12. Toplam yetişkin figürler içinde kadın ve erkek figürlerinin gösterildiği mekânlara göre frekans ve yüzde dağılımlan

\begin{tabular}{lllllll}
\hline & \multicolumn{2}{l}{ Kadın figürler } & \multicolumn{2}{l}{ Erkek figürler } & \multicolumn{2}{l}{ Toplam } \\
\cline { 2 - 7 } & $\mathrm{f}$ & $\%$ & $\mathrm{f}$ & $\%$ & $\mathrm{f}$ & $\%$ \\
\hline Ev ve Ev Çevresi & 10 & 3,38 & 13 & 4,39 & 23 & 7,77 \\
\hline Okul ve Okul Çevresi & 4 & 1,35 & 1 & 0,34 & 5 & 1,69 \\
\hline Diş Mekân & 16 & 5,41 & 95 & 32,09 & 111 & 37,5 \\
\hline Kurum ve Kuruluş & 5 & 1,69 & 11 & 3,72 & 16 & 5,41 \\
\hline İş Ortamı & 21 & 7,09 & 84 & 28,38 & 105 & 35,48 \\
\hline Belirsiz & 2 & 0,68 & 34 & 11,49 & 36 & 12,16 \\
\hline Toplam & 58 & 19,59 & 238 & 80,41 & 296 & 100 \\
\hline
\end{tabular}

Tablo 12'de toplam yetişkin kadın ve erkek figürlerin hangi mekânlar içinde gösterildiğini incelediğimizde; iki grubun da daha çok dış mekân ve iş ortamı içerisinde gösterildikleri görülmüştür. Kendi cinsiyetleri içerisindeki dağılımlara baktığımızda erkeklerin kadınlardan daha fazla dış mekânlarda (\% 37,5), iş ortamlarında (\%35,48), ev ve ev çevresinde (\% 7,77), kurum ve kuruluşlarda $(\% 5,41)$ gösterildikleri belirlenmiştir. Öte taraftan sadece okul ve okul çevresinde bulunma oranı açısından kadın figürlerin bu mekânlarda erkeklere oranla daha fazla gösterildiği görülmüştür.

Bu durum erkeklerin hayatın sosyal alanlarında kadınlardan daha çok yer aldıklarını vurgulaması açısından ders kitaplarının geleneksel erkek ve kadın rollerine bakış açısını yansıttı̆̆ını söylemek mümkündür.

Ortaokul sosyal bilgiler ders kitaplarnnda yer alan görsel öğelerde yetişkin kadın ve erkekler hangi mesleklerde gösterilmektedirler?

Mesleklerin sınıflandırılmasında 2014 yılında Türkiye İstatistik Kurumu (TÜIK, 2018) tarafından hazırlanan ISCO 08 adlı uluslararası standart meslek sınıflaması referans alınmıştır. Buna göre incelenen ders kitaplarındaki meslek kategorileri şöyledir: Profesyonel meslek mensuplarl; Teknisyenler, teknikerler; Yardımcı profesyonel meslek mensupları; Hizmet ve satış elemanları; Sanatkârlar ve ilgili işlerde çalışanlar; Tesis ve makine operatörleri ve montajcıları; Nitelik gerektirmeyen işlerde çalışanlar. 
Tablo 13. Kadın ve erkek figürlerin gösterildiği mesleğe göre frekans ve yüzde dă̆ılımları

\begin{tabular}{lllllll}
\hline & \multicolumn{2}{c}{ Kadın figürler } & \multicolumn{2}{l}{ Erkek figürler } & \multicolumn{2}{l}{ Toplam } \\
\cline { 2 - 8 } & $\mathrm{f}$ & $\%$ & $\mathrm{f}$ & $\%$ & $\mathrm{f}$ & $\%$ \\
\hline Yöneticiler & 8 & 2,70 & 69 & 23,31 & 77 & 26,01 \\
\hline Profesyonel meslek mensupları & 19 & 6,42 & 117 & 39,53 & 136 & 45,95 \\
\hline Teknisyenler, teknikerler & 2 & 0,68 & 13 & 4,39 & 15 & 5,07 \\
\hline Yardımcı profesyonel meslek mensupları & 0 & 0 & 4 & 1,35 & 4 & 1,35 \\
\hline Büro hizmetlerinde çalışan elemanlar & 0 & 0 & 4 & 1,35 & 4 & 1,35 \\
\hline Hizmet ve satış elemanları & 4 & 1,35 & 6 & 2,03 & 10 & 3,38 \\
\hline $\begin{array}{l}\text { Nitelikli tarım ormanclık ve su ürün } \\
\text { çalışanı }\end{array}$ & 7 & 2,36 & 10 & 3,38 & 17 & 5,74 \\
\hline Tesis ve makine operatörleri & & & & & & \\
\hline Belirsiz & 0 & 0 & 6 & 2,03 & 6 & 2,03 \\
\hline Toplam & 18 & 6 & 9 & 3,04 & 27 & 9,12 \\
\hline
\end{tabular}

Tablo 13'te incelenen kitaplarda yetişkin kadın ve erkek figürlerin genel toplamda bir meslek içinde yer verilme oranlarına baktığımızda yetişkin kadın figürler yönetici mesleklerinde \% 2,70, erkek figürlerin ise $\% 23,31$ oranında yer almıştır. Profesyonel meslek grubuna ait mesleklerde kadınlar \% 6,42, erkek figürle \% 39,53 oranlarında; teknisyenler, tekniker grubuna mensup mesleklerde kadınlar $\% 0,68$, erkekler $\% 4,39$ oranında; hizmet ve satış sektörüne mensup mesleklerde kadınlar \% 1,35, erkekler \% 2,03 oranlarında yer aldıkları görülmüştür. Mesleksel anlamda gösterilme sayısındaki büyük fark dikkat çekmektedir.

İncelenen kitaplarda erkeklerin sırasıyla bilim insanı, iş adamı, aşçı, çiftçi, temizlikçi, sağlık çalışanı, şoför, oto tamircisi, iş makinası operatörü, maden mühendisi, arama kurtarma görevlisi, gazeteci, ressam, matematikçi, fizikçi, bankacı, maden işçisi, arıcı, veteriner, orman mühendisi, orman işçisi, belediye başkanı, öğretmen, yazar, edebiyatçı, şair, padişah, sporcu, asker, pilot, zabıta, polis, tekstil işçisi, milletvekili, bakan, fotoğrafçı, gemi kaptanı, fabrika işçisi, astronot, robot teknisyeni, iklim mühendis, biyolog, pompacı, terzi, balıkçı, tiyatrocu oldukları görülmektedir.

Kitaplarda kadın figürlerin temsil ettikleri meslekler öğretmen, hemşire, turist rehberi, ziraat mühendisi, gıda mühendisi, maden mühendisi, tarım işçisi, doktor, polis, televizyon haber spikeri, muhtar gibi meslekler olmuştur. Sonuç olarak erkek figürlerin temsil ettiği meslek alanları kadın figürlerin temsil ettiği mesleklerden çok daha fazla olduğu görülmektedir. 
Ortaokul sosyal bilgiler ders kitaplarnda yer alan görsel öğelerde kız ve erkek çocuklar hangi objelerle gösterilmektedirler?

Tablo 14. Kız ve erkek figürlerin birlikte gösterildiği objelere ilişkin frekans ve yüzde dağılımları

\begin{tabular}{lllllll}
\hline & \multicolumn{3}{l}{ Kız figürler } & \multicolumn{2}{l}{ Erkek figürler } & \multicolumn{2}{l}{ Toplam } \\
\cline { 2 - 7 } & $\mathrm{f}$ & $\%$ & $\mathrm{f}$ & $\%$ & $\mathrm{f}$ & $\%$ \\
\hline Oyun ile ilgili Objeler & 6 & 4,08 & 5 & 3,40 & 11 & 7,48 \\
\hline Öğrenimle İlgili Objeler & 17 & 11,56 & 14 & 9,52 & 31 & 21,08 \\
\hline Toplumsal Yaşamla İlgili Objeler & 6 & 4,08 & 8 & 5,44 & 14 & 9,52 \\
\hline Doğa ile ilgili Objeler & 6 & 4,08 & 4 & 2,72 & 10 & 6,80 \\
\hline İş ile ilgili Objeler & 24 & 16,33 & 30 & 20,41 & 54 & 36,73 \\
\hline İlgi Alanlarıla İlgili Objeler & 6 & 4,08 & 3 & 1,36 & 9 & 6,12 \\
\hline Diğer & 10 & 6,80 & 8 & 5,44 & 18 & 12,24 \\
\hline Toplam & 75 & 51,02 & 72 & 48,98 & 147 & 100 \\
\hline
\end{tabular}

İncelenen kitaplarda kız ve erkek çocuk figürlerin hangi objelerle birlikte gösterildiğine baktığımızda her iki cinsiyetten figürlerin öncelikle iş ile ilgili objelerle (\% 36,73), öğrenimle ilgili objelerle (\% 21,08), toplumsal yaşamla ilgili objelerle (\% 9,52) gösterildiği görülmüştür.

Kız çocuk figürlerinin sırasıyla en çok iş ile ilgili objelerle (\% 16,33), öğrenimle ilgili objeler $(\% 11,56)$, oyun ile ilgili objeler $(\% 4,08)$, toplumsal yaşam ile ilgili objelere $(\% 4,08)$ birlikte yer verildiği görülmüştür. Erkek figürlerin ise sırasıyla en çok iş ile ilgili objelerle (\% 20,41), öğrenimle ilgili objelerle (\% 9,52), toplumsal yaşam ile ilgili objelerle (\% 5,44) gösterildiği görülmüştür.

\section{Sonuç ve Öneriler}

Araştırmada elde edilen bulgular sonucunda, sosyal bilgiler 5, 6 ve 7. sınıf ders kitapları cinsiyet rolleri açısından incelenmiş, kitapların görsel öğelerinde toplumsal cinsiyet kalıp yargılarının yeniden üretilmesi ve pekiştirilmesine yönelik bulgular belirlenmiştir. Araştırmada ortaokul sosyal bilgiler ders kitaplarında yer alan görsel öğelerde yetişkin kadın ve erkekler ile kız ve erkek çocukların kimlerle birlikte gösterildikleri, hangi eylemlerle, hangi mekânlarda, hangi mesleklerde ve hangi objelerle gösterildikleri incelenmiş ve cinsiyetçiliğe dayalı bir söylemi desteklendiği tespit edilmiştir.

Araştırmada elde edilen bulgular doğrultusunda şu sonuçlar elde edilmiştir: 
1- Araştırmada incelenen görsellerin içinde yer alan kız ve erkek çocuk figürlerin \% 51'i kız, 49'u erkek çocuk figürüdür. Bu anlamda kız ve erkek çocukların sosyal bilgiler kitaplarında temsil edilme oranları neredeyse eşittir. Araştırmada incelenen ders kitaplarında toplam çocuk sayısı üzerinden kız ve erkek çocuk figürlerinin en çok çocuklarla, tek başına ve yetişkinlerle gösterildiği belirlenmiştir. Kız çocuk figürleri erkek çocuk figürlerine oranla daha çok çocuklarla gösterilirken, erkekler daha çok tek başına gösterilmişlerdir. Kız çocuk figürlerin ailesiyle birlikte ve kalabalık ile birlikte gösterilme oranı, erkeklerinkinden yüksektir. Bu durum kızların korunmaya daha fazla ihtiyacı olduğu yönünde bir vurguyu barındırdığı izlenimini uyandırabilmektedir. Kız çocuk figürlerin aileleriyle birlikte gösterilme oranının yüksek olması, erkek çocukların ise tek başına ve kalabalık ile gösterilme oranının yüksek olması; çocukların büyüdüklerinde taşıması beklenen cinsiyet rollerine yönelik izler barındırdığını söylemek mümkündür.

İncelenen görsel öğelerde yetişkin kadın ve erkek figürlerin temsil edilme oranına baktığımızda erkeklerin oranının kadın figür oranından oldukça yüksek olduğu tespit edilmiştir. Kadın yetişkin figürlerin gösterilme oranı \% 19,59 olurken, erkek yetişkin figürlerin oranı \% 80,41 olmuştur. Her iki grubu kimlerle gösterildikleri açısından karşılaştırdığımızda yetişkin kadın figürlerin tek başına gösterilme oranının, yetişkin erkek figürlerin gösterileme oranından oldukça düşük olduğu belirlenmiştir. Erkek figürlerin en çok tek başına ve diğer erkeklerle gösterildiği, çocuklarla ve kadınlarla birlikte gösterilme durumuna kadın figürlerden daha az yer verildiği görülmüştür. Kadın figürler ise en çok çocuk ve diğer kadınlarla birlikte gösterilmiştir. Yetişkin kadın ve erkek figürlerin geleneksel cinsiyet rollerine uygun birliktelikler içinde gösterilmesi dikkat çekmektedir. Çocuk figürlerden ziyade yetişkin kadın ve erkek figürlerin cinsiyet rollerine dair kalıpyargıları daha yoğun taşıması araştırmanın diğer bulgularında da karşılaşılacak bir durum olarak ortaya çıkmıştır.

2- İncelenen kitapların görsellerinde kız ve erkek figürler en çok okula ve öğrenmeye yönelik eylemlerde, sosyal eylemlerde ve eylemsiz olarak gösterildikleri görülmüştür. İncelenen kitapların görsellerinde kız ve erkek figürlerin yaptıkları eylemlere bakıldığında kız figürlerin sırasıyla eylemsiz, okula ve öğrenmeye yönelik eylem içinde, sosyal eylemler içinde, diğer eylemlerde, kültür ve sanata yönelik eylemlerde, evdeki eylemlerde, oyun ve eğlenceye yönelik eylemler içinde gösterilmiştir. Erkek çocuk figürler ise, sırasıyla okula 
ve öğrenmeye yönelik eylemler, sosyal eylemler, eylemsiz, diğer eylemler, oyun ve eğlenceye yönelik eylemler içinde gösterilmişlerdir. Kız çocuk figürler ile erkek çocuk figürleri karşılaştırdığımızda kız çocukların erkeklerden daha çok eylemsiz halde gösterildikleri, bunun yanı sıra evdeki eylemlerde, kültür ve sanata yönelik eylemlerde kız çocuklara erkeklerden daha çok yer verildiği; erkek çocuk figürlere ise okula ve öğrenmeye yönelik eylemler, oyun ve eğlenceye yönelik eylemler, spora yönelik eylemler, sosyal eylemlerde kızlardan daha çok yer verildiği görülmüştür.

İncelenen görsellerde hem kadın hem erkek yetişkin figürler en çok işe yönelik eylemlerde, eylemsiz, sosyal eylemlerde, kültürel/sanatsal eylemlerde, çocuğa yönelik/çocukla ilgili eylemlerde gösterilmişlerdir. Kadınların sırasıyla işe yönelik eylemlerde, sosyal eylemlerde, boş zamana yönelik eylemlerde, çocuğa yönelik/çocukla ilgili eylemlerde gösterildiği görülmektedir. Erkek figürlerin ise sırasıyla en çok işe yönelik eylemlerde, eylemsiz, sosyal eylemlerde, boş zamana yönelik eylemlerde, kültür ve sanata yönelik eylemlerde gösterildiği görülmüştür.

İncelenen kitaplardaki görsel fotoğraflarda toplam yetişkin figürleri içinde kadın figürler eve yönelik eylemlerde ve çocuğa yönelik/çocukla ilgili eylemlerde erkeklerden daha çok yer alırken; erkekler ise boş zamana yönelik eylemler, kültürel/sanatsal eylemler, işe yönelik eylemler, sosyal eylemler açısından kadınlardan daha çok yer buldukları tespit edilmiştir. İşe yönelik eylemler açısından erkek ve kadın figürler arasındaki temsil oranı farkı en yüksektir. Buradaki bulgular da incelenen ders kitaplarının toplumsal cinsiyet rollerine ilişkin kalıpyargısal bakış açısını taşıdığına işaret etmektedir.

3- Toplam çocuk figürleri içinde kız ve erkek figürlerinin gösterildiği mekânları incelediğimizde kız ve erkek çocuk figürlerin daha çok okul ve okul çevresinde, diş mekânlarda ve ev ve ev çevresinde gösterildikleri belirlenmiştir. Kız figürler en çok dış mekânda, okul ve okul çevresinde, ev ve ev çevresinde gösterilirken; kurum ve kuruluşlarda en az gösterilmiştir. Erkek çocuk figürler ise en çok, okul ve okul çevresinde, dış mekânda, ev ve ev çevresinde gösterilmiştir. İncelen kitaplarda kız çocuklarının ev ve ev çevresinde gösterilme oranları erkeklerin ev ve ev çevresinde gösterilme oranından daha fazla iken; erkek çocuk figürlerin okul ve okul çevresinde, dış mekânda gösterilme oranları ise kızlara göre daha yüksek olmuştur.

Yetişkin kadın ve erkek figürlerin, toplam sayısı üzerinden, hangi mekânlar içinde gösterildiğini incelediğimizde; iki grubun da daha çok diş 
mekân ve iş ortamı içerisinde gösterildikleri görülmüştür. Kendi cinsiyetleri içerisindeki dağılımlara baktığımızda erkeklerin kadınlardan daha fazla dış mekânlarda, iş ortamlarında kurum ve kuruluşlarda gösterildikleri belirlenmiştir. Öte taraftan sadece okul ve okul çevresinde bulunma oranı açısından kadın figürlerin bu mekânlarda erkeklere oranla daha fazla gösterildiği görülmüştür. Bu durum erkeklerin hayatın sosyal alanlarında kadınlardan daha çok yer aldıkları ve bu durumun ders kitaplarının erkek ve kadın rollerine bakış açısını yansıttığını söylemek mümkündür.

4- İncelenen kitaplarda yetişkin kadın ve erkek figürlerin, genel toplamda, bir meslek içinde yer verilme oranları incelendiğinde yetişkin kadın figürlerin yönetici mesleklerinde \% 2,7, erkek figürlere ise \% 23,31 oranında temsil edildiği dikkat çekmiştir. Profesyonel meslek grubuna ait mesleklerdeki kadın ve erkek temsillerinde de benzer bir sonuç ortaya çıkmıştır. Teknisyenler, tekniker grubuna mensup mesleklerde; hizmet ve satış sektörüne mensup mesleklerde de fark daha küçük olmakla birlikte yetişkin erkek figürlerin daha çok temsil edildiği görülmektedir. Mesleksel temsil açısından yetişkin kadın ve erkek figürlerin arasındaki büyük fark dikkat çekmektedir. Bu bağlamda erkek figürlerin temsil ettiği meslek alanlarının kadın figürlerin temsil ettiği mesleklerden çok daha fazla olduğu görülmüştür.

5- İncelenen kitaplarda kız ve erkek çocuk figürlerin hangi objelerle birlikte gösterildiğine de bakılmıştır. Her iki cinsiyette de iş ile ilgili objelerle, öğrenimle ilgili objelerle, toplumsal yaşamla ilgili objelerle gösterilme oranı ilk sıralarda yer almıştır. Kız figürleri sırasıyla iş ile ilgili objelerle, öğrenimle ilgili objelerle, oyun ile ilgili objelerle, toplumsal yaşam ile ilgili objelerle gösterilmişlerdir. Erkek çocuk figürler ise sırasıyla iş ile ilgili objelerle, öğrenimle ilgili objelerle, toplumsal yaşam ile ilgili objelerle gösterilmişlerdir.

Araştırmada sosyal bilgiler 5, 6 ve 7. sınıf ders kitaplarında cinsiyet rolleri açısından incelenmiş ve kitapların görsel öğelerinde toplumsal cinsiyet kalıp yargılarının yeniden üretilmesi ve pekiştirilmesine yönelik bulgular belirlenmiştir. Araştırmada ortaokul sosyal bilgiler ders kitaplarında yer alan görsel öğelerde yetişkin kadın ve erkekler ile kız ve erkek çocukların kimlerle birlikte gösterildikleri, hangi eylemlerle, hangi mekânlarda, hangi mesleklerde ve hangi objelerle gösterildikleri incelenmiş ve bulgulara göre ders kitaplar1nın cinsiyetçi bir söylemi desteklediği görülmüştür.

Okulların bir toplumda bireylerin dünyayı görme ve anlamlandırma biçimlerinin şekillenmesinde düşünce ve fikirlerinin oluşmasında önemli rol 
oynadığı düşüncesinden hareketle cinsiyet eşitliğinin sağlanmasında da önemli rol oynayabilirler. Bunun için de toplumsal cinsiyet eşitliğine duyarlı kuşaklar yetiştirmek, buna uyun eğitim programları hazırlamak, ders kitapları geliştirmek toplumsal cinsiyet eşitliği konusunda farkındalık yaratmak önemli hale gelmektedir.

Modern toplumlarda toplumsal cinsiyet rollerinde kadın ve erkek arasındaki eşitlik meselesi son derece önem verilen bir kondur. Kadınlar ve erkekler arasındaki eşitsizlik bir insan hakları sorunu, bir sosyal adalet sorunu olarak düşünülmekte, aynı zamanda eşitlik, kalkınma ve refahın vazgeçilmez unsuru olarak düşünülmektedir. UNICEF'in 2003 yılında hazırladığı ‘Eğitimin Toplumsal Cinsiyet Açısından incelenmesi' raporunda öğretim programında veya öğrenme/öğretme materyallerinde ve/veya ders kitaplarında cinsiyet rollerinden arındırma çalışmalarının gerçekleşmediği bildirilmiştir.

UNICEF eğitimin her düzeyi için toplumsal cinsiyete duyarlı öğretim programlarının oluşturulmasının önemini belirterek çocuk ve yetişkinlerin değişen toplumsal cinsiyet rolleri ve sorumlukları çerçevesinde, eğitim materyallerinin kalıplaşmış cinsiyet rollerinden arındırması gerektiğini bunun için politikalar geliştirilmesi gerektiğini vurgulamaktadır (UNICEF, 2003).

Cinsiyet eşitsizliği konusunun bir insan hakları sorunu çerçevesinde değerlendirip bunun önüne geçilmesi açısından diğer kurumlarla işbirliği yapılması, farklı bilim alanlarının bir araya gelerek ortak çalışmalar üretmesi ve bu çalışmaların sonuçlarının göz önünde bulundurularak eğitim politikalarına dönüştürülmesi önem kazanmaktadır. Ders kitapları yeni kuşaklara, cinsiyet eşitliği konusunda bir farkındalık ve bilinç oluşturulması açısından önemli eğitim araçlarıdır. Bu durum, kitapların hazırlanmasında rol oynayan komisyon görevlilerinin cinsiyet ayrımcılığı konusunda uzman olmasını gerektirmektedir. 


\title{
EXTENDED ABSTRACT
}

\section{Gender Roles in Social Studies Textbooks Levels}

\author{
Mehmet Tahir Karaboğa \\ Mersin University
}

The aim of this study is to examine the visual elements in social studies textbooks taught in secondary schools in terms of gender roles. In the study, the visual elements in the secondary school social studies textbooks were examined in terms of with whom, in what actions, in which places, in which professions and with what objects adult women and men and girls and boys were shown. The sample of the research includes visual items in the 5, 6, and 7th grade social studies textbooks selected by the Ministry of National Education to be taught in secondary schools in the 2019-2020 academic year. This study is a qualitative study and includes a document analysis technique and a content analysis on the visuals in the social studies textbooks. In the research, it has been determined that the visuals in the secondary school social studies textbooks contain elements based on gender roles. It is seen that textbooks contribute to teaching, reinforcement and reproduction of genderbased roles in this way. The findings reveal that the images of boys and girls and adult women and men in the secondary school social studies textbooks contain gender stereotypes.

In line with the findings obtained in the research, the following results were obtained:

1. A total of 443 images that constitute the sample of the research and included in 3 social studies textbooks were examined. $1 \%$ of the figures in images examined in the study were girls and $49 \%$ were boys. In this sense, the representation rates of girls and boys in social studies books are almost equal. In the textbooks examined in the study, it was determined that the figures of girls and boys are shown with children, alone and adults, respectively. While the figures of girls are shown more with the children than the figures of boys, the rate of showing the boys alone is higher. In addition, the rate of girls being shown with their families and the crowd is higher than that of boys.

When we look at the ratio of adult female and male figures in the visual items examined, it is seen that the ratio of female figures is $19,59 \%$ and male 
figures are $80,41 \%$. In this sense, the proportion of male figures in the images in the books was significantly higher than that of female figures. When we compare both groups in terms of who they are shown with, it was determined that the rate of representing adult female figures alone is significantly lower than that of adult male figures.

2. In the images included in the textbooks examined, it was observed that the figures of boys and girls are shown mostly in school and learning related actions, social actions and as inactive. When the actions performed by the male and female figures in the examined images were compared, it was found that the female figures were shown inactive, in school and learning actions, in social actions, in other actions, in culture and art actions, in actions at home, in games and entertainment actions, respectively. Male figures are shown in school and learning related actions, in social actions, inactive, in other actions, in games and entertainment actions, respectively.

In the images examined, both female and male adult figures were most often shown in work-oriented actions, inactive, in social actions, in cultural / artistic actions, in child-oriented / child-related actions. It is seen that women are shown in work-related actions, social actions, leisure activities, child oriented / child related actions, respectively. On the other hand, it was seen that male figures were shown mostly in work-oriented actions, inactive, social actions, leisure-oriented actions, and cultural and artistic actions.

In the visuals in the books examined, female figures were more involved in home-directed and child-related / child-related actions than men; on the other hand, it was determined that men find more places than women in terms of leisure activities, cultural / artistic actions, work-oriented actions, and social actions. The difference in the representation rate of male and female figures in terms of work-oriented actions is the highest.

3. When the places where girls and boys are shown are examined, it is determined that the figures of girls and boys are mostly shown around the school and school, outdoors and around the house and home. While the female figures are mostly shown outdoors, around the school and school environment and home; they were shown leastly in institutions and organizations. The figures of boys on the other hand are mostly shown in school and school environment, outdoors and around the house. 
4. When the ratio of the inclusion of adult female and male figures in a profession is compared, it was found that adult female figures were represented in the executive professions by $2.7 \%$ and male figures by $23.31 \%$. A similar result has emerged in the representation of women and men in professions. Although the difference is smaller in technician-related occupations and in the occupations related to the service and sales sector, it is seen that adult male figures are more represented.

5. In the books which are the subject of the study, it was also examined with which objects the girl and boy figures are shown. The ratio of being shown with work-related objects, learning-related objects, and social-life objects in both genders ranks first. Girl figures were shown mostly with workrelated objects, learning-related objects, game-related objects, and social-life objects. Boy figures, on the other hand, were shown mostly with businessrelated objects, learning-related objects, and social-life objects.

\section{Kaynakça / References}

Alpan Özdemir, E. D. (2018).Toplumsal cinsiyet kalıp yargılarının çocuk oyunlarına yansıması. Atatürk Üniversitesi GSF Sanat Dergisi, 80-89.

Altan Arslan, Ş. (2000). Ders kitaplarında cinsiyetçilik. Ankara :T.C. Başbakanlık Kadının Statüsü ve Sorunları Genel Müdürlüğü.

Balcı Karaboğa, A. (2019). Kültür, çocuk ve toplumsal cinsiyet. D. Aslan, M. Kale, İ. Nur (Ed.), Kültür ve çocuk içinde (s. 189-214). Ankara: Pegem Akademi yayınları.

Batur, Z. (2010). Ana dili öğretiminde gösterge biliminin yeri: ana dili ders kitaplarındaki sözel metinlerle görsel metinleri bütünselliğinin analizi. Turkish Studies: International Periodical For the Languages, Literature and History of Turkish or Turkic, 5(4), 174-200

Bay, E. (2011). Eğitim bilimleri ile ilgili temel kavramlar. Remzi Y. Kıncal (Ed.), Eğitim Bilimlerine Giriş içinde (s.11-25). Ankara: Grafiker Yayınları.

Bhasin, K. (2003). Toplumsal cinsiyet: bize yüklenen roller. (K. Ay, Çev.). İstanbul: Kadın Dayanışma Vakfı Yayınları.

Butler, J. (2008). Cinsiyet belast: Feminizm ve kimliğin altüst edilmesi. İstanbul: Metis Yayınları.

Connell , R.W.(2019).Toplumsal cinsiyet ve iktidar. (C. Soydemir, Çev.). İstanbul: Ayrıntı Yayınları. 
Çabuk Kaya, N. (2013). Türkiye'de toplumsal cinsiyet eşitliği ve eğitim. 12 Ekim 2019 tarihinde http://kizlarinegitimi.meb.gov.tr/files/img/toplum_cinsiyet_ve_egitim.pdf adresinden erişildi.

Çakır, P. (2013). Türkçe ders kitaplarındaki öykülerin çocuğa görelik ilkesi açısından incelenmesi. Turkish Studies, International Periodical For The Languages, Literature and History of Turkish or Turkic, 8(1), 1171-1180.

Demirel, E. (2010). Sosyal bilgiler ders kitaplarında cinsiyet ayrımcilı̆̆ı. Yayımlanmamış yüksek lisans tezi Dokuz Eylül Üniversitesi, İzmir.

Demirel, Ö. ve Kıroğlu, K. (2006). Konu alanı ders kitabı incelemesi. Ankara: Pegem A Yayincilik.

Dökmen, Z. Y. (2016). Toplumsal cinsiyet - sosyal psikolojik açıklamalar. İstanbul: Remzi Kitabevi.

Esen Severge, Y. (1998). Ders kitaplarında cinsiyetçilik: İlköğretim ders kitapları üzerinde yapılmış bir içerik çözümlemesi. Yayımlanmamış yüksek lisans tezi, Ankara Üniversitesi Sosyal Bilimler Enstitüsü, Ankara.

Fidan, N. ve Erden M. (1996). Eğitime giriş. Ankara: Alkım Kitapçılık Yayıncllık. Francis, B. (2006). The nature of gender. Skelton, C., Francis, B. ve Smulyan, L. (Ed.). The sage of handbook of gender and education içinde (s. 7-18). London: Sage Publication Ltd.

Gümüşoğlu, F.(2016). Ders kitaplarnnda toplumsal cinsiyet 1928'den günümüze. İstanbul: Tarihçi Kitapevi Yayınları.

Gündüz Kalan, Ö. (2010). Reklamda çocuğun toplumsal cinsiyet teorisi bağlamında konumlandırılışı: 'kinder' reklam filmleri üzerine bir inceleme. İstanbul Üniversitesi Illetişim Fakültesi Dergisi, 1(38) , 75-89.

Jacklin, C. N. (1983). Boys and girls entering school. In M. Marland (Ed.), Sex Differentiation and schooling (p.8-17). London: Heinemann Educational Books.

Kılavuz, T. (2019). Ilkokulda cinsiyet ayrımcllı̆̆ının yeniden üretimi. Yayınlanmamış Yüksek lisans tezi. Mersin Üniversitesi Eğitim Bilimleri Enstitüsü, Mersin.

Kitiş Çınar, E. (2013). Ortaokul Türkçe ders kitaplarında toplumsal cinsiyet. Yayımlanmamış yüksek lisans tezi. Pamukkale Üniversitesi, Denizli.

Kuzgun, Y. ve Sevim, S. A. (2004). Kadınların çalışmasına karşı tutum ve dini yönelim arasındaki ilişki. Ankara Üniversitesi Eğitim Bilimleri Fakültesi Dergisi, 37(1), 14-27. 
MacNaughton, G. (2006). Constructing gender in early- years education. Skelton, C. , Francis, B. ve Smulyan, L. (Ed.).The sage of handbook of gender and education içinde ( s.127-139) London: Sage Publication Ltd.

MEB. (2018). Sosyal bilgiler dersi öğretim programi: İlkokul ve Ortaokul 4, 5, 6 ve 7. Sınıflar. Ankara: T.C. Millî Eğitim Bakanlığı. 10 Kasım 2019 tarihinde http://mufredat.meb.gov.tr/Dosyalar/201812103847686-SOSYAL\%20B\%C4\%B0LG\%C4\%B0LER\%20\%C3\%96\%C4\%9ERET\%C4\%B0 M\%20PROGRAMI\%20.pdf adresinden erişildi.

Oakley, A. (1972). Sex, gender and society. London: Temple Smith.

Özdemir, E. ve Balcı Karaboğa, A. (2019). Ortaokul matematik ders kitaplarında toplumsal cinsiyet. Mersin Üniversitesi Ĕ̆itim Fakültesi Dergisi, 15(3), 760781. DOI: 10.17860/mersinefd.580405.

Tavşancil, E., ve Aslan, E. (2001). İçerik analiz ve uygulama örnekleri. İstanbul: Epsilon.

TBMM. (1993). CEDAW komitesine verilen ikinci ve üçüncü birleştirilmiş periyodik Türkiye raporu. Ankara. 10 Kasım 2019 tarihinde https://www.tbmm.gov.tr/komisyon/kefe/belge/uluslararasi_belgeler/ayrimcilik/CEDAW/ulke_raporlari/CEDAW\%20Komitesi'ne\%20verilen $\% 20 \mathrm{~T} \%$ C3\%9CRK\%C4\%B0YE\%20RA-

PORU\%202\%20ve\%203.\%20d\%C3\%B6nem.pdf adresinden erişildi.

TBMM. (1999). Kadına yönelik her türlü ayrımcilı̆̆ın önlenmesi sözleşmesi'nin 4. maddesinin 1. paragrafinda yer alan geçici özel önlemlerle ilgili 25 sayıl genel tavsiye. 10 Kasim 2019tarihinde https://www.tbmm.gov.tr/komisyon/kefe/belge/uluslararasi_belgeler/ayrimcilik/CEDAW/tavsiye_kararlari/CEDAW\%20Komitesi\%20Tavsiye\%20Kararlar\%C4\%B1_(1-29).pdf adresinden erişildi.

Tezcan, M. (1996). Eğitim sosyolojisi. Ankara: Feryal Matbaası.

Tezer Asan, H. (2010). Ders kitaplarında cinsiyetçilik ve öğretmenlerin cinsiyetçilik algılarının saptanması, Fe Dergi, 2(2), 65-74. Erişim adresi: https://dspace.ankara.edu.tr/xmlui/bitstream/handle/123456789/62762/16748.pdf?sequence=1

Tietz, W. M. (2007). Women and men in accounting textbooks: Exploring the hidden curriculum, Issues In Accounting Education, 22(3), 459-480. 
TÜIK, (2018). Meslek smıflamaları. 10 Aralı 2019 tarihinde https://biruni.tuik.gov.tr/DIESS/SiniflamaSurumListeAction.do;jsessionid=qBgOtr4Q-Aq9cnlXxYjEwjvF?turAdi=+9.+Meslek+S\%C4\%B1n\%C4\%B1flamalar\%C4\%B1\&d-495879-o=2\&tu$\mathrm{rId}=41 \&$ guncel $=\mathrm{Y} \& \mathrm{~d}-495879-\mathrm{s}=1$ adresinden erişildi.

UNICEF. (2003). Eğitimin toplumsal cinsiyet açısından incelenmesi raporu. https://www.unicef.org/turkey/raporlar/e\%C4\%9Fitimin-toplumsal-cinsiyet-a\%C3\%A7isindan-incelenmesiturkiye-2003 adresinden erişilmiştir.

Ünsal , Y.,Güneş, B. (2002). Bir kitap inceleme çalışması örneği olarak MEB ilköğretim 4. sınıf fen bilgisi ders kitabına fizik konuları yönünden eleştirel bir bakış. Gazi Üniversitesi Gazi Eğitim Fakültesi Dergisi, 22(3), 107-120.

Vatandaş, C. (2011). Toplumsal cinsiyet ve cinsiyet rollerinin algılanışı. Sosyoloji Konferanslarl, 35, 29-56. 15 Aralı 2019 tarihinde http://dergipark.gov.tr/iusoskon/issue/9517/118909 adresinden erişildi.

Yıldırım, A. ve Şimşek, H. (2013). Sosyal bilimlerde nitel araştırma yöntemleri (Genişletilmiş 9. Baskı). Ankara: Seçkin Yayıncılık.

Yıldırım, A., ve Şimşek, H. (2018). Sosyal bilimlerde nitel araştırma yöntemleri. Ankara: Seçkin Akademik ve Mesleki Yayınlar.

Yurtsever, K. (2011). Ilköğretim II. kademe öğretmenlerinin öğrencilere yönelik tutumlarının cinsiyet değişkenine göre incelenmesi. Yayımlanmamış yüksek lisans tezi, Eğitim Bilimleri Enstitüsü, Sakarya.

\section{Kaynakça Bilgisi / Citation Information}

Karaboğa, T. (2020). Sosyal bilgiler ders kitaplarında cinsiyet rolleri. OPUS-Uluslararası Toplum Araştırmaları Dergisi, 15(10. Yıl Özel Say1s1), 4847-4881. DOI: 10.26466/opus.686709 